\title{
EMPLOYMENT RELATIONSHIPS IN THE NEW ECONOMY
}

\author{
David Neumark \\ Deborah Reed
}

Working Paper 8910

http://www.nber.org/papers/w8910

\author{
NATIONAL BUREAU OF ECONOMIC RESEARCH \\ 1050 Massachusetts Avenue \\ Cambridge, MA 02138 \\ April 2002
}

We are grateful to Van Swearingen and Amanda Bailey for outstanding research assistance. Neumark is Professor of Economics at Michigan State University and a Research Associate of the NBER. Reed is a Research Fellow and Director of the Population Program at the Public Policy Institute of California. Any opinions expressed are those of the authors alone and do not necessarily reflect any position of the Public Policy Institute of California. The views expressed herein are those of the authors and not necessarily those of the National Bureau of Economic Research.

(C) 2002 by David Neumark and Deborah Reed. All rights reserved. Short sections of text, not to exceed two paragraphs, may be quoted without explicit permission provided that full credit, including $\odot$ notice, is given to the source. 
Employment Relationships in the New Economy

David Neumark and Deborah Reed

NBER Working Paper No. 8910

April 2002

JEL No. J00

\begin{abstract}
It is often argued that "new economy" jobs are less likely to use traditional employment relationships, and more likely to rely on "alternative" or "contingent" work. When we look at new economy jobs classified on the basis of employment in high-tech industries, we do not find greater use of contingent or alternative employment relationships. However, when we classify new economy workers based on residence in high-tech cities, contingent and alternative employment relationships are more common, even after accounting for the faster employment growth in these cities. Finally, defining "new economy" more literally to be those industries with the fastest growth yields the most striking differences, as workers in the fastest-growing industries are much more likely to be in contingent or alternative employment relationships, with a large share of this difference driven by employment in the fast-growing construction and personnel supply services industries where employment is perhaps "intrinsically" contingent or alternative. While subject to numerous qualifications, the combined evidence gives some support to the hypothesis that the new economy may entail a possibly significant and long-lasting increase in contingent and alternative employment relationships.
\end{abstract}

David Neumark

Department of Economics

Michigan State University

East Lansing, MI 48824

and NBER

neumarkd@msu.edu
Deborah Reed

Public Policy Institute of California

500 Washington Street, Suite 800

San Francisco, CA 94111

reed@ppic.org 


\section{$\underline{\text { I. Introduction }}$}

While many commentators have tried to define the "new economy," researchers have only recently begun to grapple with defining the new economy, exploring its consequences, and testing hypotheses regarding what makes the new economy "new." In our view, one important set of hypotheses regards consequences for the nature of the employment relationship. In particular, it is often argued that new economy jobs are less likely to use traditional employment relationships, and more likely to rely on "alternative" or "contingent" work. The goal of this paper is to explore evidence on whether the new economy is indeed associated with less-traditional employment relationships.

The "new economy" means many things to many people, although all emphasize to some extent the role of information technology and the information sector of the economy. ${ }^{1}$ One set of definitions refers broadly to an economy that operates differently from the past in some fundamental way. Thus, to some investors the "new economy" means (or meant) a world in which stock market valuations do not depend in the usual ways on earnings and other fundamentals, a view spurred in particular by the financial performance of information technology companies (at least prior to the recent sharp declines in the NASDAQ). ${ }^{2}$ To Federal Reserve Chairman Alan Greenspan, it apparently refers to productivity gains driven by information technology that allow (or allowed) the economy to grow at a fast pace without igniting inflation. ${ }^{3}$ An alternative macroeconomic perspective is that information technology has reduced the component of the business cycle driven by inventory fluctuations. ${ }^{4}$ To businesspeople, it may mean a world that rewards innovation and new concepts more than machinery and production, ${ }^{5}$ as well as an increasingly globalized marketplace. ${ }^{6}$ These "aggregate" definitions of the new economy have been the

\footnotetext{
${ }^{1}$ See DeLong and Summers (2001) for a review of many "views" of the new economy. To emphasize the dramatic role of information technology, they suggest that the past 40 years have witnessed a four-billion-fold increase in the world's raw computational power (p. 17).

${ }^{2}$ See D'Andrea Tyson (2001). For evidence on this hypothesis, see Bond and Cummins (2000).

${ }^{3}$ See Miller (2001). For evidence on this hypothesis, see Gordon (2000) and Black and Lynch (2000).

${ }_{5}^{4}$ See DeLong and Summers (2001).

${ }^{5}$ See Encyclopedia of the New Economy (hotwired.lycos.com/special/ene/).

${ }^{6}$ See Shepard (1997).
} 
dominant foci in writing on the new economy in the popular media, most likely because the discussion occurred largely in the context of rather striking macroeconomic and financial-market developments.

However, a second set of definitions of the new economy-more germane to this paper-focuses more on the world of work, arguing that new types of jobs are emerging that may share some common features, and are different from the old. ${ }^{7}$ Frequently the identification of such jobs is tied to the broader definitions of the new economy mentioned above. For example, the sectors thought to be fueling productivity gains-such as software, financial services, media, and consulting-are sometimes viewed as new economy industries. ${ }^{8}$ Reich (2001) focuses on the increasing demand in the new economy for creative and innovative talent as opposed to the talent to bring products to the market. Finally, a more "mechanical" definition of new economy jobs is simply those that are growing the fastest; assuming this faster growth continues, such jobs will clearly represent a larger share of whatever new economy emerges. ${ }^{9}$

Definitions of the new economy based on the world of work naturally raise questions about whether jobs in the new economy are different from jobs in the old economy, and what the implications of these differences are for workers, firms, and labor market institutions and policies. In particular, there are at least three reasons to believe the development of the new economy may foretell changes in the employment relationship. First, an extensive literature has recently developed documenting changes in the employment relationship in the United States in the latter part of the 1990s. This literature generally did not establish dramatic and fundamental changes in the employment relationship, giving lie to assertions that long-term jobs were disappearing. It did, though, appear to establish two results. First, workers who had previously experienced among the most stable and secure jobs-most notably, perhaps, more-educated and older workers in managerial and professional occupations-had begun in the 1990s to experience decreased job stability and job security. ${ }^{10}$ Second, although comparable data over time are hard to come by, it is fairly

\footnotetext{
${ }^{7}$ There are also other microeconomic characterizations of the new economy that do not focus so much on the world of work, emphasizing the non-rival nature of information-related goods (DeLong and Summers, 2001), and different cost structures in new economy industries, in particular high fixed costs and low variable costs (Varian, 2001).

${ }^{8}$ See Mandel (1999).

${ }^{9}$ See U.S. Department of Commerce (2000).

${ }^{10}$ See, e.g., Neumark, et al. (1999) and Valletta (1999).
} 
clear that there has been growth over the 1990s in workers employed in flexible staffing arrangements. ${ }^{11}$

The simple coincidence of the timing of changes in the employment relationship and the apparent emergence of the new economy naturally raises the question of the link between the new economy and the employment relationship.

The second reason to examine whether and how the new economy impacts the employment relationship is that some of the technological changes that are conjectured to underlie high productivity growth are likely to influence the labor market. One potential channel of influence includes the hypothesized link between the growth of computer use in the workplace and increases in the demand for more-educated workers. ${ }^{12}$ A second, more directly tied to the employment relationship, concerns the role of technology in general, and information technology in particular, in changing the organization of work and production systems and sometimes the nature of the goods or services produced. ${ }^{13}$

The third motivation for investigating the link between the new economy and the employment relationship is simply the popular view that the advent of the new economy threatens traditional employment relationships. Commentators from a variety of quarters often describe new economy jobs as inherently unstable, and relying on non-traditional or "contingent" forms of employment. A few examples follow:

- "In the new economy, the employer/employee employment relationship has been turned upside down. Employees no longer stay with a single company for their entire career...A key to guaranteeing employment and income security for new economy employees is to ensure that they are equipped with the skill base to easily move from one job to the next...Companies are shifting to

\footnotetext{
${ }^{11}$ See Houseman and Polivka (2000), who cite evidence from the Upjohn Institute Employer Survey on Flexible Staffing Arrangements, and discuss other evidence.

${ }^{12}$ See, e.g., Autor, et al. (1998).

${ }^{13}$ See, e.g., Batt (1999), Bresnahan, et al. (1999) and work reviewed therein, and earlier related work on the implications of the rise of "technicians" for the organization of work, described in Barley (1996).
} 
a smaller core workforce, which is supplemented with a contingent workforce that has the skills needed at the moment." 14

- "There is nothing inevitable or preordained that requires New Economy jobs to be cheap-wage, non-union, and insecure. But it is up to us to challenge the New Economy evangelists who preach their anti-union gospel."15

- "Many new economy jobs hire contractors, not employees. The theory is that they will bring you on, give you no benefits, pay you for the project they hire you for, and then let you go."16

This paper addresses the hypothesis embodied in the above quotes-that the new economy challenges and changes the nature of the employment relationship, reducing reliance on "traditional" employment, and increasing the use of "contingent" or "alternative" work arrangements (including but not limited to use of contractors). While conjectures about the impact of the new economy on the employment relationship abound, we are aware of no evidence based on representative samples of workers on which these conjectures are based.

The fundamental difficulty in an empirical analysis of this question is operationalizing the phrase "new economy." As explained above, the phrase has many meanings, and only a subset of them-in particular, those that define the new economy based on jobs-point to direct links between the new economy and the employment relationship, and lead to feasible strategies for exploring these links by distinguishing between "new economy" and "traditional economy" jobs. Even then, these latter definitions provide relatively little guidance in identifying jobs that characterize the new economy. Thus, a major substantive concern in this paper is trying to identify such jobs.

\footnotetext{
${ }^{14}$ Business and Industry Advisory Committee to the OECD (2001).

${ }_{16}^{15}$ Bahr (2000).

${ }^{16}$ Triplett (2000).
} 
Information on the nature of the employment relationship is more readily available. In particular, the Current Population Survey (CPS) Contingent and Alternative Employment Arrangements Supplements (often referred to as the Contingent Work Supplements, or CWS) elicit information on workers describing the nature of their employment relationship in considerable detail. Thus, after specifying a number of reasonable ways of defining new economy jobs, the nature of the employment relationship in these and other jobs is compared using the CWS data.

\section{Identifying New Economy Workers}

Because we are studying the link between the new economy and the employment relationship, our attempts to identify new economy workers rely on those perspectives that most closely tie the definitions of the new economy to the types of jobs people do. However, we want to emphasize two important qualifications. First, even among this limited set of perspectives on the new economy, definitions are frustratingly vague. Thus, while we have chosen some methods of identifying new economy workers that seem to be consistent with both some of the commentary about the new economy and common sense, we by no means intend to claim that our methods are definitive. Rather, we hope to "get the ball rolling" with regard to research on this question, using some plausible and sensible classification schemes that may also motivate other researchers to think about and propose alternatives.

Second, if the new economy is more appropriately defined along dimensions other than the jobs people do, then our classification-by dividing workers into groups that do not correspond to the real distinction-may come up with little difference between new economy and other workers, when in fact the differences exist. As an example, if the new economy is defined primarily by how work is organized, and the distribution of new economy "workplaces" has little to do with the ways we usually define the jobs people do, we may end up looking at a classification of workers that has little to do with new economy versus traditional economy jobs, and hence incorrectly conclude that new economy jobs are not characterized by different employment relationships. Similarly, but farther afield, if the new economy is defined as a world in which investors look at factors other than economic fundamentals in deciding upon the allocation of financial capital, there is no necessary link to job-based distinctions among workers. On 
the other hand, by using a multiplicity of definitions of new economy workers, we may nonetheless manage to pick up some of these distinctions. As an example, a definition based on industries with the fastest growth may capture those industries to which capital is flowing, and a definition based on high-tech employment may highlight those industries in which technology-driven transformation of the workplace is more prevalent. With these qualifications stated, the remainder of this section describes the methods we use to classify new economy workers.

\section{High-Technology Industries}

Our first classification of new economy workers is based on employment in high-tech industries.

One common focus in discussions of the new economy is the emphasis on technology and knowledge in the workplace. To some extent, the focus is on work in the information technology sector. ${ }^{17}$ More generally, though, this perspective focuses on work that relies heavily on technology and that rewards knowledge and innovation more than production. ${ }^{18}$ Thus, the first approach we use to classifying new economy workers is one based on employment in what might be considered "new economy industries," based on heavy reliance upon technological and scientific personnel.

To avoid picking and choosing industries in a subjective manner that might influence the results, we use a Bureau of Labor Statistics (BLS) study (Hecker, 1999) that seeks to identify "high-technology industries." The BLS study uses a definition of high-tech industries based on employment of workers in two categories: technology-related occupations, and research and development. ${ }^{19}$ Industries are then classified as high-tech if the proportion of employment in both of these categories is at least twice the average for all industries. This yields a list of 25 Census industries, which are displayed in Table 1. It

\footnotetext{
${ }^{17}$ As an example, the strike at Verizon by the Communications Workers of America was billed by some as the first major battle between unions and the new economy (Boslett, 2000). See also the comments of Paul David in Schiffrin (2000).

${ }^{18}$ See, e.g., Reich (2001), and the assertion in the Encyclopedia of the New Economy (hotwired.lycos.com) that, "When we talk about the new economy, we're talking about a world in which people work with their brains instead of their hands."

${ }^{19}$ The occupational information comes from the Occupational Employment Statistics (OES) Surveys covering 1993, 1994, and 1995. The technology-related occupations include: engineers; life and physical scientists; mathematical specialists; engineering and science technicians; computer specialists; and engineering, scientific, and computer managers. Research and development workers in the OES are identified in these occupations, as well as a variety of others (see Hecker, 1999, p. 19).
} 
includes many industries readily recognizable as high-tech-such as computers and related equipment, and scientific and controlling instruments. But it also includes some industries-such as plastics, synthetics, and resins, as well as paints, varnishes, and related products-not commonly thought of as high-tech, but which nonetheless use a fair amount of scientific personnel. ${ }^{20}$

An important point that Hecker makes is that the classification of high-tech industries he uses is relatively robust. In particular, he provides a comparison of the industries chosen by his criteria with those chosen in two earlier BLS reports, and notes the substantial overlap. This implies that the results we obtain using the industry list in this 1999 BLS report are unlikely to reflect idiosyncratic features of this particular list. Indeed, the study also provides a comparison to lists of high-tech industries from non-BLS studies, and these too have substantial overlap with the 1999 BLS report, although they tend to be narrower. Thus, there is reason to believe that most reasonable lists of high-tech industries would coincide relatively closely with the ones on which we base our analysis.

Among the high-technology industries, there are seven that can be classified as informationtechnology industries according to the U.S. Department of Commerce (1999). These seven are indicated in the second column of Table 1. We also investigate contingent and alternative employment based on this more restricted definition of information-technology industries.

\section{High-Technology Cities}

Our second method of classifying new economy workers relies more on geography, classifying workers based on employment in cities with high concentrations of high-tech employment. A definition of new economy workers based solely on employment in industries employing a disproportionately high number of technological or scientific personnel may miss two important dimensions of new economy jobs. First, some jobs or industries associated with the new economy may rely heavily on computers and software, but not in a technological capacity. Second, there may be jobs that "grow up" around the hightech sector that are not intensive users of scientific or technological personnel. An example that might fit

\footnotetext{
${ }^{20}$ Hecker defines a narrower list of "high-technology intensive industries," covering 9 SIC industries that are arguably more closely tied to traditional definitions of high-tech. However, a number of these industries are combined with industries not in this subset in going from SIC to Census industries.
} 
both of these descriptions is employment in dot-com companies involved in a variety of service provision businesses-jobs that may capture the innovative and knowledge-based nature of new economy jobs, yet not have a strong scientific or technical component, or at least not be classified as scientific or technical occupations. Alternatively, in an effort to be flexible, dynamic, and focused, high-tech start-ups may be more likely than traditional companies to use personnel supply services for out-sourcing non-technical positions such as janitorial and clerical support. In such a case we would expect to see more contingent and alternative work in high-tech cities but not necessarily among workers in high-tech jobs.

To try to classify workers in a manner that moves away from purely industry-based measures, but captures workers in high-tech industries as well as the jobs that cluster around them geographically, our second classification of new economy workers is based on those employed in cities categorized as "hightech." Use of this label for cities has become commonplace-applied to places like Silicon Valley, Seattle, Boston, etc.--with these cities typically viewed as the centers of the new economy. ${ }^{21}$ By looking at all workers in high-tech cities, we should capture relatively more people in jobs in high-tech industries and occupations, as well as those in the industries and occupations that tend to exist or arise in proximity to clusters of high-tech employment.

Again, to avoid making subjective selections of cities that might influence our results, we sought a list of high-tech cities from an external research source. In fact, paralleling to some extent the lists of hightech industries that researchers have compiled, a few research institutes have recently tried to come up with lists of high-tech cities. We chose to rely on a Brookings Institution study (Cortright and Mayer, 2001). This study begins with a list of 14 high-tech cities that, according to the authors, are those "most frequently mentioned in the popular literature" (p. 9). It then ranks these cities based on relative employment in the following industries-computer and electronic product manufacturing, software publishers, information services and data processing services, and computer systems design and related services ${ }^{22}$-and provides an

\footnotetext{
${ }^{21}$ See, e.g., Paton (1999) and Sunnucks (2001).

22 These industries are based on the North American Industry Classification System (NAICS).
} 
overall ranking based on relative employment in these industries. The top 10 cities based on this overall ranking, on which we focus our analysis, are displayed in the first column of Table $2{ }^{23}$

By way of contrast, a recent study by the Progressive Policy Institute (PPI, 2001) uses a wide variety of indicators to identify high-tech cities. Most of them are not based on employment (and when they are, factors like educational level are used, rather than working in the high-tech sector), and quite a few of the indicators relate to technology directly (such as domain-name registrations, computers in schools, broadband providers, etc.). However, like with the BLS industry classification discussed above, alternative methods of classifying cities come up with quite similar lists. In particular, 7 of the top 10 cities in the Brookings ranking are also in the top 10 cities in the PPI ranking, and the remaining 3 cities in the Brookings top 10 are ranked 11,15 , and 16 in the PPI ranking. ${ }^{24}$ Conversely, the 3 cities in the PPI top 10 not included in the Brookings top 10 are included in the original list of 14 cities with which the Brookings study begins. ${ }^{25,26}$

Finally, while the motivation for looking at high-tech cities is to capture jobs related to high-tech industries although not necessarily in these industries, the list of high-tech cities tends, not surprisingly given the way the list was selected, to include cities with large shares of high-tech workers. This is illustrated in the second column of Table 2, which shows the share of each city's employment in the new economy industries based on high-tech employment (from Table 1), computed from CPS data. ${ }^{27}$ These range from a high of 36 percent in San Jose, to a low of 11 percent in Phoenix. By way of comparison, the

\footnotetext{
${ }^{23}$ Given that the original universe of 14 cities was not chosen based on a systematic data analysis, we thought it preferable to take a subset of these 14 that actually ranked highest on an objective measure.

${ }^{24}$ These three cities are, respectively, Atlanta, Portland, and Phoenix. The Brookings study looks at the San Jose Primary Metropolitan Statistical Area (PMSA), which does not include San Francisco, whereas the PPI study uses an area that combines San Jose and San Francisco (using Consolidated Metropolitan Statistical Areas). In doing these comparisons between the two lists of cities, we have treated these as the same areas.

${ }^{25}$ These are Raleigh-Durham, Washington, and Salt Lake City.

${ }^{26}$ Another study of high-tech cities, from the Milken Institute (DeVol, 1999), is based on high-tech industry output (as a share). However, this study includes many very small cities, such as Lubbock, TX, Pocatello, ID, and Atlantic-Cape May, NJ. As these cities are too small to study reliably with the CPS data, this classification of cities is somewhat less useful. Nonetheless, 11 of the 14 cities in the original Brookings list are in the top 50 cities reported in the Milken study.

${ }^{27}$ In this and all subsequent CPS calculations, observations are dropped if allocated data were needed to identify a worker's industry. City codes were not allocated. City codes were not included in 1995 CWS and we therefore exclude 1995 data from the analysis of high-tech cities. We verified that excluding 1995 from our other analyses does not qualitatively affect the main results (reported in Tables 6 and 8).
} 
last row presents the share for other comparable cities not on the list, ${ }^{28}$ which is just over 10 percent. For the other high-tech cities, high-tech employment is over-represented by a ratio of about 1.3 to 2 .

\section{High-Growth Industries}

Finally, we use a classification of new economy workers based on employment in the fastestgrowing industries. The fastest-growing industries, whether or not they have a strong technological basis, are destined to be a growing part of the economy, and thus in a mechanical sense-as long as their higher growth rates persist-are destined to be increasingly important in the new economy. It would not be entirely surprising, of course, if some of the industries chosen on the basis of high-tech employment are also among the fastest-growing industries, since the equating of "high-tech employment" and "new economy" in the popular view is no doubt linked in part to the growth of the former. But other factors such as changing demographic structure and changing levels and distribution of income may also-via demand shifts-impact which jobs are becoming more prevalent in the economy.

To identify the fastest-growing industries, we used CPS Outgoing Rotation Group (ORG) files to measure employment growth by Census industry from 1996 to 2000. Growth was calculated as the change in the industry's employment share from 1996 to 2000. To avoid outliers caused by inaccurate measurements, only industries with an employment share of at least .25 percent in 2000 were considered. Among these, we took the 20 industries with the highest growth. ${ }^{29}$ These are listed in Table 3.

Three industries chosen on this criterion overlap with new economy industries based on high-tech employment, with computer and data processing services first on the list. But none of the other 22 hightech industries are among the 20 fastest-growing industries, and indeed quite a few industries with little obvious relationship to high-tech employment or technology more generally appear, including: construction, elementary and secondary schools; child day care services; offices and clinics of physicians;

\footnotetext{
${ }^{28}$ This consists of 51 non-high-tech cities that have a minimum of about 500,000 workers. This cutoff was chosen to include cities as small as the smallest city in the list in Table 2 (Austin, with just over 570,000 workers), thus enabling a comparison of cities in similar size ranges.

${ }^{29}$ The choice of a cut-off of 20 for the growth classification was arbitrary. We also looked at results using a cut-off of 10 (matching the number of high-tech cities) and 25 (matching the number of high-tech industries). The differences between high-growth industries and other industries reported below were qualitatively similarly based on any of these cut-offs.
} 
etc. At the same time, quite a few industries that might be associated with a growing emphasis on information or information technology also appear, including: credit agencies, n.e.c.; security, commodity brokerage, and investment companies; and telephone communications.

If we had to categorize the high-growth industries generally, however, perhaps their most striking feature is their concentration in services. Of the 20 industries, 5 of the top 10 and 9 of the top 20 are in service industries, defined to include business services, personal services, or professional and related services. Thus, defining new economy industries based on growth rather than high-tech employment generates a list of industries overrepresented by the "service economy." This is of interest becausealthough it may have preceded the emphasis on the new economy in the popular media-frequent reference has been made to the transition of the U.S. economy (and other developed economies) into service-oriented economies (e.g., Albrecht and Zemke, 1985; Giarini, 1987; Inman, 1985; Ginzberg, 1984). Thus, workers in industries selected on the basis of growth may highlight an older definition of the new economy, based on services.

One noteworthy industry that shows up on the list of fast-growing industries is personnel supply services. This industry has been cited in prior work as one of the fastest-growing industries and the industry at the forefront of the growth in contingent and alternative work arrangements (Houseman and Polivka, 2000; Segal and Sullivan, 1997). ${ }^{30}$ This is a prime illustration of the difference between selecting new economy industries based on growth rather than on high-tech employment, and suggests that the former may reveal more important differences in the employment relationship.

Finally, recall that part of the reason for going from a classification of new economy jobs based on high-tech industries to one based on high-tech cities was to capture jobs that tend to surround high-tech industries. One would certainly expect that the industries that are both high-growth and high-tech would be

\footnotetext{
${ }^{30}$ Among workers in temporary help agencies (as measured in the CWS), personnel supply services is the most common industry ( 49 percent). The next most common are health services n.e.c. ( 3 percent), construction ( 2 percent), and computer and data processing services (2 percent).

As Segal and Sullivan explain, this industry includes temporary service employees, as well as employee leasing and employment agencies. However, the trend in growth is very similar in an industry trade group series they present that focuses solely on temporary service employees, and temporary service employees represent nearly 90 percent of workers in the personnel supply services industry.
} 
overrepresented in high-tech cities, since it is presumably the fast growth of high-tech industries that warrants the label for the city. That this is the case is illustrated in the second column of Table 4 . This column shows that the 3 new economy industries based on the fastest growth (from Table 3 ) that are similarly classified based on high-tech employment (from Table 1) are over-represented in every high-tech city and, for half of the cities, over-represented by a factor of more than 1.5. To better understand the nature of these high-tech cities, it is interesting to ask whether the other (17) high-growth industries in Table 3 also make up a disproportionately large share of employment in these cities. As shown in the last column of Table 4, this is not the case; the employment shares of these industries in the high-tech cities are near the share in the comparison cities, and generally a bit lower. This indicates that the selection of new economy industries based on growth seems to pick up many industries that are neither high-tech themselves nor particularly related to high-tech industries, which further reinforces the point that a growth-based new economy classification is in some ways fundamentally different from a technology-based one.

\section{Classifying the Employment Relationship}

The Contingent Work Supplements (CWS) to the Current Population Survey provide a useful classification of the employment relationship that characterizes each worker's job. In particular, these supplements were designed with the express goal of measuring the shares of the workforce in a variety of non-traditional employment relationships, as well as, of course, to collect labor market information on these workers (Polivka, 1996). The supplements focus on two types of non-traditional relationships-contingent work and alternative employment.

To be defined as a contingent worker, two conditions must hold. ${ }^{31}$ First, the individual must be in a job that is temporary, and in which an individual cannot work as long as he or she wishes. Second, an attempt is made to distinguish jobs that are temporary by their nature, compared with jobs that might be temporarily held by a worker who expects to choose to leave (for example, a youth working in a "permanent" fast-food job, but only expecting to remain in it temporarily). Only jobs of the first type are

\footnotetext{
${ }^{31}$ Details on the classification of contingent and alternative employment are taken from Hipple (1998).
} 
considered contingent. ${ }^{32}$ Within that broad definition, the BLS generally uses three definitions of contingent workers, going from more to less restrictive. The most strict definition is wage and salary workers who expect their job to last 1 year or less and have been in the job 1 year or less. The selfemployed and independent contractors are excluded. Workers with temporary help agencies or contract companies are included if both 1-year criteria apply to their position with the temporary help agency or contract company. The second definition adds in the self-employed and independent contractors for whom both 1-year criteria apply. It also adds in workers with temporary help agencies or contract companies for whom both 1-year criteria apply to their current assignment. Finally, the least restrictive definition drops the 1-year tenure criterion for wage and salary workers.

The classification of workers in alternative employment arrangements is simpler, as this is simply a mutually exclusive classification by the following categories: independent contractors (including consultants and freelance workers, and irrespective of whether they identify themselves as wage and salary workers or self-employed); on-call workers; temporary help agency workers; and workers provided by contract firms. Note that some of these workers may also be counted in some definitions of contingent workers. Finally, with these definitions in hand, it is simple to classify workers dichotomously as either in any contingent/alternative arrangement, or a traditional (non-contingent/non-alternative) arrangement.

The CWS files available for analysis are based on surveys conducted in February of 1995, 1997, 1999, and 2001. In the remainder of this section we present some descriptive statistics of contingent and alternative work arrangements, before turning to the main analysis, in the next section, of the relationship between these work arrangements and new economy jobs. The first fact to point out is that at least over the short period captured by these four surveys, the proportions of workers in each type of employment arrangement were relatively stable. These figures are reported in columns (1)-(4) of Table 5. ${ }^{33}$ Looking, for example, at the broadest contingent work category, the percentage declines from 4.9 in 1995 to 4.0 in

\footnotetext{
${ }^{32}$ Workers in temporary jobs respond that the job "could not last as long as they wish" and that they are "expecting their job to last a year or less for non-personal reasons."

${ }^{33}$ Data were not allocated in the CWS files, and observations with missing data needed to classify workers by contingent or alternative status (and subcategories within these) were dropped.
} 
2001. The percentage in any alternative arrangement was 9.8 in 1995 and 9.4 in $2001 .^{34}$ The percentage in a "catch-all" category of any contingent or alternative arrangement declined from 13.2 to 12.1 over the same period. Certainly over this short period there is no sign of increased percentages of employment in contingent or alternative arrangements. ${ }^{35}$

The absence of an upward trend in contingent and alternative work has some bearing on one issue regarding the interpretation of the phrase "new economy," discussed earlier. In particular, we noted that some definitions of the new economy do not pertain to the types of jobs workers do, but rather pertain to more widespread changes in the economy, in which case our inquiry into the relationship between the employment relationship and new economy jobs might miss the mark. The fact that employment relationships as captured in contingent and alternative work arrangements have not increased over the latter part of the 1990s suggests there was no major shift in employment relationships over time that might be associated with widespread changes in the economy. ${ }^{36}$ However, because the CWS data are only available during the recent period of rapid economic growth, we cannot distinguish business-cycle effects from the longer-run time trend; while we do not see an increase in contingent and alternative work, this may be related to tight labor markets during economic growth and not the longer-run trend. On the other hand, to the extent that the downturn had begun by February 2001, there appears to be no associated increase in contingent work and only a slight, statistically insignificant, increase in alternative work relative to 1999. Given the short period covered by the CWS and the similarity across these years in the prevalence of contingent and alternative work, we do not focus on changes over time in these employment arrangements, but focus instead on the cross-sectional relationship between employment in new economy jobs and the employment relationship, using the combined information from the pooled Contingent Work Supplements.

\footnotetext{
${ }^{34}$ Despite the growth in the personnel supply services industry, there has not been growth in temporary help agency employment due to a decline in the use of temporary help agency workers in other industries.

${ }^{35}$ See also Cohany (1998) and U.S. Department of Labor (1999) which produce similar estimates by year (for the earlier years).

${ }^{36}$ For additional evidence on changes in the employment relationship more broadly defined, with a particular emphasis on job stability and job security, see the papers in Neumark (2000).
} 
Combining across the years of the CWS, the figures indicate that 4.4 percent of workers are employed in a contingent relationship, 9.6 percent in an alternative arrangement, and 12.6 percent in any contingent or alternative employment relationship, as shown in column (5). Finally, the last two columns of the table report figures for two restricted versions of the sample. In column (6) those workers not in school either full-time or part-time are dropped. We believe it is potentially useful to isolate contingent and alternative work among non-students, as students may be likely to choose contingent work, in particular, as a result of their student status that may make both place of residence and type of work only temporary. The descriptive statistics are consistent with this, as the incidence of each type of contingent work (although not alternative employment relationships) is lower among non-students. Finally, column (7) further imposes an age restriction of 18-65 (inclusive), to abstract from very young workers sampling jobs while settling on a career, and older workers who may be pursuing short-term employment as part of partial retirement. Imposing this age restriction slightly reduces the incidence of contingent work and alternative work. In the ensuing analysis we use the sample excluding those in school and focusing on prime-age workers 18 to 65 (inclusive). ${ }^{37}$

The final rows of Table 5 report the share of workers in the combined category of "contingent or alternative" work by education level. Workers with a Bachelor's degree or more education are more likely to be in contingent or alternative jobs compared to workers with a high school diploma or less education. For both sets of workers there was a decline in non-traditional work over the late 1990s.

\section{$\underline{\text { IV. The Employment Relationship among New Economy Workers }}$}

Having discussed the classification of new economy jobs, and of the employment relationship, we finally turn to the relationship between the two. The empirical analysis we present is straightforward. We first report differences in the incidence of contingent or alternative work in new economy jobs vs. other jobs, based on our three alternative classifications of new economy jobs. We then allow for the possibility

\footnotetext{
${ }^{37}$ Our focus is on contingent or alternative work arrangements. However, another possible dimension of nontraditional employment related to the new economy includes self-employment, as illustrated, perhaps, by the apparent increased prevalence of "start-ups" in the high-tech sector. Thus, we also looked at self-employment in a parallel fashion to all of the analyses reported below. To establish a baseline, self-employment rates in the CPS averaged just under 11 percent across the 1995-2001 CWS files, declining somewhat over the sample period.
} 
that individual characteristics such as age, sex, race, etc., are correlated with the likelihood that workers are in new economy jobs, as well as the likelihood that they are in contingent or alternative employment relationships, estimating linear probability models of the form: ${ }^{38}$

(1) $\mathrm{CA}=\alpha+\beta \mathrm{NE}+\mathrm{X} \gamma+\varepsilon$.

In this generic regression, $\mathrm{CA}$ is a dummy variable for a particular contingent or alternative employment relationship, or a combined set of these. NE is a dummy variable indicating that the individual is employed in a new economy job, based on one of our three classifications, and $\mathrm{X}$ is a vector of individual control variables, including: age; the square of age; a full set of dummy variables for educational attainment; a dummy variable for female; interactions of the female dummy variable with age and its square and the education dummy variables; a set of dummy variables for black, Hispanic, Asian, and other non-whites; and a dummy variable for foreign born. The estimate of $\beta$ therefore measures the shift associated with employment in a new economy job in the probability that a worker is in a particular contingent or alternative employment relationship, for workers otherwise identical in terms of the variables captured in X. Finally, other controls are sometimes added that are intended to further probe the interpretation of the estimate of $\beta$; these are explained in describing the analysis for each of the three new economy classifications.

New Economy Jobs Based on Employment in High-Technology Industries

Differences in the employment relationship in new economy jobs using a classification based on high-technology employment are reported in Table 6. Columns (1) and (2) report the percentages in each type of employment relationship in new economy jobs based on this classification, and in other jobs, while column (3) reports the difference between the two. For all three categories of contingent work, the percentage with contingent employment relationships is lower in new economy industries, by about .6 percentage point using the two more restrictive contingent work measures, and .9 percentage point using

\footnotetext{
${ }^{38}$ Due to the limited nature of the dependent variable in the linear probability model, we report boot-strapped standard errors based on 200 iterations. Boot-strapped standard errors tend to be larger than White-corrected (i.e., robust) standard errors. For the linear probability model, we prefer the boot-strapped standard errors to relax assumptions on the distribution of the residual terms.
} 
the broadest measure. The results are a bit more varied for alternative employment relationships. Employment as an independent contractor or on-call worker is less prevalent in new economy industries (by 1.8 and 1.2 percentage points, respectively), while employment by a temporary help agency or contract firm is more prevalent (by .4 and 1.2 percentage points, respectively). Overall, in new economy industries employment in alternative employment relationships is lower by 1.5 percentage points, and employment in any contingent or alternative relationship is lower by 2.5 percentage points.

In column (4), the individual-level control variables are added. Generally speaking, these have little impact on the estimated differentials in the employment relationship between new economy industries and other industries. The only sizable difference stems from the reduced relative incidence of employment as an independent contractor in new economy industries, which ultimately increases the overall shortfall of contingent or alternative employment in new economy industries to 3.3 percentage points.

The analysis in Table 6 is intended to focus on the intrinsic differences between industries based on a comparison of high-technology and other industries. But the industries may differ along other dimensions as well. We cannot, of course, include industry dummy variables to capture these other sources of differences, as our new economy classification is industry-based. But it is important to control for other industry-related differences that might be strongly associated with contingent or alternative employment relationships. The most natural one that raises concerns is industry growth. High-technology industries are likely to be among the faster-growing industries in this sample period (as already illustrated in part by the overlap between Tables 1 and 3), and it is useful to parse out the independent association of contingent or alternative employment relationships with employment in high-tech industries. Consequently, we add to the regression a variable measuring the growth of the industry's share of employment; including this control is likely to, if anything, push the results in the direction of lower incidence of contingent or alternative work in new economy jobs. In addition, we control for the overall size of the industry, as larger or smaller industries may differ in their use of non-traditional employment relationships. ${ }^{39}$

\footnotetext{
${ }^{39}$ Details on the construction of these control variables are given in the notes to Table 6 .
} 
The results are reported in the fifth column of Table 6 . The estimates for contingent employment relationships are changed slightly, in the direction of lower relative prevalence among new economy jobs. The changes in the estimates for alternative arrangements are similarly modest and typically in the same direction. The only substantive change, perhaps, is that the higher use of temporary help agency employment in new economy industries is no longer apparent in the data after including these industry growth and size controls.

The final column of Table 6 limits our definition of new economy industries to those hightechnology industries that are also information-technology industries (see Table 1). ${ }^{40}$ We find that contingent and alternative work overall is even less common in information-technology industries; looking at the separate categories, the sole exception is that contract firm employment is more common in information-technology industries.

When the analysis is done by education level (final rows), with only the individual-level controls, the lower mean level of contingent or alternative work in high-tech industries is due to the lower level among workers with a high school diploma or less. However, once we control for industry size and growth, high-tech employment is associated with a lower prevalence of non-traditional work for both highly-educated workers and less-educated workers, although more so for the latter group. ${ }^{41}$

Overall, then, there is virtually no evidence that employment relationships in new economy industries based on a high-technology classification are more likely to take non-traditional forms. The only exception is contract firm employment, which is higher by about 1 to 2 percentage points in these industries. Rather, in contrast to some of the claims and perceptions discussed in the introduction, most contingent or alternative employment relationships are less prevalent in new economy industries when defined by high-technology employment. As a summary measure, the regression estimates with the full set of controls indicate that the percentage of workers in non-traditional employment relationships is 5.7

\footnotetext{
${ }^{40}$ Workers in industries listed in Table 1 that are not information-technology industries are still included in the regression for column 6 .

${ }^{41}$ For less-educated workers the regression has a dummy variable for less than a high school diploma. For moreeducated workers the regression has a dummy variable for degree attainment beyond the Bachelor's. Each education dummy variable is interacted with a dummy variable for female workers.
} 
percentage points lower in new economy industries than in other industries; relative to the sample mean of about 12.6 percent of the workforce in such arrangements, this implies that contingent or alternative employment relationships are 45 percent less prevalent in new economy industries. ${ }^{42}$

In order to understand the role of each new economy industry in driving the results in Table 6, we replaced the new economy industry dummy variable with a separate dummy variable for each of the 25 new economy industries in Table 1 (regression not shown). ${ }^{43}$ Compared to the aggregate of other or "old economy" industries, 7 of the 25 new economy industries had a higher rate of contingent work (under the broadest definition) but none these higher rates were statistically significant at the 10 percent level and for only one of these industries-manufacturing of office and accounting machines-was the estimated rate greater than 1 percentage point more than old economy industries. For any alternative relationship, every new economy industry had a lower rate except for management and public relations services, where the rate was almost 22 percentage points higher than in old economy industries. We found a similar result when we combined contingent or alternative work. Every new economy industry except management and public relations services had a lower rate of contingent or alternative work than the aggregate of old economy industries, with the differences almost always statistically different from zero at the 5 percent level. This indicates that the failure to find more use of contingent or alternative work arrangements among high-tech industries is not attributable to the inclusion of industries that use scientific personnel extensively but are not typically thought of as high-tech-such as paints, petroleum, or plastics. Rather, even when looking at industries individually, those more typically associated with computers and information technology generally exhibit lower-not higher-use of contingent or alternative employment.

\section{New Economy Jobs Based on Residence in High-Technology Cities}

This conclusion could differ, of course, using other definitions of new economy jobs. Attention next turns to the definition based on high-tech cities. Differences in the employment relationship in new economy jobs classified by high-technology cities are reported in Table 7. As before, columns (1) and (2)

\footnotetext{
${ }^{42}$ Paralleling these findings, the results also pointed to lower self-employment in high-tech industries, with a differential of 7.6 percentage points in the specification corresponding to column (5) of Table 6.

${ }^{43}$ The regression controls were the same as in the final column of Table 6.
} 
report the percentages in each employment relationship in new economy jobs based on this classification, and in other jobs, while column (3) reports the difference between the two. In contrast to the results based on high-tech employment, for the classification based on high-tech cities almost all of these differences are in the direction of greater prevalence of contingent or alternative work in new economy jobs (with many of the differences statistically significant at the 5 percent level). For the broadest definition of contingent work, the percentage with contingent employment relationships is higher in new economy cities, by about .7 percentage point. Among alternative work arrangements, prevalence is higher in these cities for independent contractor, temporary help agency, and contract firm employment. Overall, the prevalence of contingent or alternative employment relationships among workers in new economy cities is higher by 1 percentage point.

Columns (4) and (5) report regression-adjusted estimates paralleling the same columns in Table 6. The individual-level controls in column (4) increase slightly the estimated differentials in contingent employment between new economy cities and other cities, and increase more sharply the estimated differential in alternative employment relationships. As a summary measure, the relative incidence of contingent or alternative employment in new economy cities rises to 1.2 percentage points. Column (5) adds controls for city size and growth, paralleling the industry-level controls in Table 6, with the same motivation of isolating the intrinsic nature of employment in these cities, aside from the possibility that employment relationships differ in larger versus smaller cities, or because of recent growth. Adding these controls raises slightly the relatively higher incidence of contingent work, with the opposite effect regarding alternative work, on net restoring a differential of 1 percentage point higher incidence of contingent or alternative work in high-tech cities.

For workers with a high school diploma or less education, residence in high-tech cities is not associated with a higher prevalence of contingent or alternative work (final rows of Table 7). Rather, the high-tech city results are mainly due to the higher prevalence of non-traditional work for workers with a college degree compared to similar workers in other places. 
To summarize, employment in high-tech cities, which is one of our methods of delineating new economy jobs, does appear to be characterized by a higher prevalence of contingent and alternative employment, at least for workers with a Bachelor's degree or more education. Based on the regression estimates in column (5), contingent employment is higher by .9 percentage point and alternative employment is higher by .4 percentage point. While these are not large differences in absolute terms, the first is sizable in relative terms, representing 25 percent higher prevalence of contingent work. Overall, in the combined category of contingent or alternative work, workers with a Bachelor's degree or more education have a 10 percent higher prevalence. ${ }^{44}$ These findings contrast rather sharply with those for new economy jobs based on employment in high-tech industries. After reporting the high-growth industry results, we explore the role of the industrial mix in high-tech cities, to better understand what drives the high-tech city results.

\section{New Economy Jobs Based on Employment in High-Growth Industries}

Finally, we turn to the third definition of new economy jobs, based simply on employment in the fastest-growing industries. As Table 3 indicated, some of the fastest-growing industries are high-tech, but by no means all of them. The results for this definition, reported in Table 8, indicate that new economy jobs are much more likely to use contingent or alternative employment relationships. Looking at columns (1)-(3), every category of contingent or alternative work is significantly more prevalent in the fastestgrowing industries. For the broadest contingent work definition, prevalence among the fastest-growing industries is higher by 2.2 percentage points. The corresponding number for alternative employment relationships is 8.0 percentage points, and for the overall contingent/alternative measure 8.3 percentage points. The differences remain virtually unchanged when the individual-level regression controls are added in column (4).

In the previous two tables, controls were added for size and growth, to try to capture other features of industries (Table 6) or cities (Table 7). Of course, in this table we are focusing on growth per se, so it

\footnotetext{
${ }^{44}$ On the other hand, self-employment is no more prevalent in these cities, with corresponding specifications indicating if anything lower prevalence (not statistically significant) once all of the controls are added.
} 
would be nonsensical to control for industry growth. However, column (5) does add a control for industry size, which leads to slight decreases in the estimated differentials for broadly-defined contingent employment and slight increases for any alternative employment. For the summary measure combining both of these, the estimated prevalence in the fastest-growing industries is higher by 8.0 percentage points, or more than 60 percent higher relative to the mean prevalence.

The most important high-growth industry for explaining the higher rates of contingent and alternative work is construction. Among the 20 new economy industries defined by fast growth, construction has the largest share of workers at almost 22 percent. Construction also has a high level of contingent work (6.5 percent using the broadest definition), alternative work ( 28 percent), and combined contingent or alternative work (32 percent). The second most important industry is personnel supply services. Although personnel supply services has very high rates of contingent work (45 percent), alternative work (69 percent), and combined contingent or alternative work ( 71 percent), the importance of this industry is limited by its small share of workers-less than 3 percent. ${ }^{45}$

To get a better idea of how the employment relationship in new economy jobs based on industry growth differs aside from the influence of these two rather idiosyncratic industries, in column (6) of Table 8 two dummy variables are added for employment in construction and personnel supply services. As expected, this sharply reduces the higher prevalence of temporary help agency employment. Correspondingly, it reduces the estimated differential for any alternative employment arrangement from 8.4 percentage points to 4.1 percentage points. Finally, because much of the employment in these two industries is contingent, the estimated differential for contingent work falls from 2.0 to .2 percentage points, and the differential prevalence for any contingent or alternative arrangement falls to 3.7 percentage points, or 30 percent relative to the mean. Thus, while eliminating consideration of construction and the personnel supply services industry reduces the extent by which new economy jobs appear to rely on contingent and alternative employment relationships, the fact still remains that new economy jobs-based on industry

\footnotetext{
${ }^{45}$ The questions used to identify workers in temporary help agencies are constructed to attempt to exclude regular employees of temporary help agencies, i.e., those who run or staff the agencies. Thus, the percentage of workers in the personnel supply services industry who are classified as "temps" can be well under 100.
} 
employment growth-do rely substantially more on non-traditional and in particular alternative employment relationships. ${ }^{46}$ We also find strong results for growth industries for both highly- and less-educated workers (final rows).

Of course, it is possible that growth, per se, contributes to the reliance on contingent and alternative workers as fast-growing industries may be more likely to use non-traditional employment relationships. High-growth industries may be experiencing what managers perceive to be a temporary increase in workload and thus there may be a preference for temporary and contingent workers. Furthermore, highgrowth industries have a large proportion of new hires who may be employed on a contingent basis to allow firms to screen workers before offering a regular position. ${ }^{47}$ In light of these considerations, we might expect that with the exception of a few particular industries such as construction and personnel supply services, high rates of contingent and alternative work in these growth industries will decline when the growth abates.

\section{The Industrial Mix of Employment in High-Tech Cities}

Finally, we report results from analyses intended to probe the higher incidence of contingent or alternative employment in high-tech cities-in particular, trying to understand whether the industrial mix of employment in these cities underlies this higher incidence. First, as we showed in Table 4, industries that are both high-tech and fast-growing are overrepresented in high-tech cities. Since high-tech employment is not associated with more contingent and alternative employment relationships, the overrepresentation of high-tech industries alone cannot explain the higher prevalence of such employment relationships in hightech cities. However, this higher prevalence could be attributable to the overrepresentation of fastergrowing industries, given the substantial differentials reported in Table 8. To assess this question, in Table 9 we add controls for industry size and industry growth (for each worker's industry) to the high-tech city

\footnotetext{
${ }^{46}$ Paralleling these findings, self-employment is considerably more prevalent in the fast-growing industries, with differentials between 3 and 4 percentage points in specifications corresponding to columns (5) and (6) in Table 8 .

${ }^{47}$ Houseman and Polivka (2000) report that the main motivation for using alternative employment relationships (in which they include part-time employment) is to handle fluctuations in the workload or regular staff. They also provide evidence that, to a lesser extent, employers use alternative employment relationships to screen workers. We have no clear way to capture this at the industry level, but it may be strongly related to industry growth.
} 
regressions (column (2)). This has little impact on the estimated differentials in contingent employment relationships between high-tech and other cities (compare with column (1), which repeats column (5) of Table 7). However, with controls for industry size and growth, the high-tech cities no longer have a significantly higher share of contract firm employment and the higher share of temporary help agency employment is also reduced, with the result that the importance of high-tech cities for any alternative employment is no longer statistically significant. Looking at the combined category of contingent or alternative work, the coefficient falls from 1.00 to .67 suggesting that roughly one-third of the higher incidence of contingent and alternative employment in high-tech cities is due to the size and growth of the industries in high-tech cities.

To explore this further, we control for the entire industrial mix in high-tech cities by adding dummy variables for each three-digit industry. The estimates remain essentially unchanged from those that control for industry size and growth (column (3)). The full regression results (not shown) reveal that three of the most important industries for explaining the higher prevalence of contingent and alternative work in high-tech cities are the three high-tech industries that are also high-growth industries (shown in bold in Table 3). When we add indicators for each of these three industries, the results are very similar to the results controlling individually for every industry (compare column (4) with column (3)). As before, we find that the high-tech city results hold for workers with a Bachelor's degree or more, but not for workers with a high school diploma or less education (final rows).

Thus, we conclude that the prevalence of high-tech and fast-growing industries in high-tech cities explains roughly one-third of the higher prevalence of contingent or alternative work in those cities. The remaining two-thirds of the higher prevalence appears to be explained by a distinction captured by our new economy classification based on high-tech cities that differs from those based on employment growth by industry and employment in high-tech industries. Thus, high-tech cities appear to capture another dimension of new economy jobs that utilize contingent and alternative employment relationships at a greater rate than do other jobs. 


\section{$\underline{\text { V. Conclusion and Discussion }}$}

The primary goal of this paper is to examine whether new economy jobs are less likely to use traditional employment relationships, and more likely to rely on "alternative" or "contingent" work. Data on contingent and alternative employment are readily available, based on recent micro-level surveys devoted to measuring employment in these types of arrangements. On the other hand, the phrase "new economy" has been used in so many ways (not all of them related to classifications of jobs) that there is, in a sense, an independent research project required to distinguish new economy jobs from other jobs. We do not claim to have the definitive method of so classifying jobs, and indeed we do not believe there is one unique classification. Instead, we develop and use three alternative classification schemes that seem like plausible candidates consistent with what we see as the main conceptions of the new economy based on the world of work: one based on employment in high-tech industries; a second based on residence (and employment) in high-tech cities; and a third based, more mechanically, on employment in fast-growing industries, which tend to be service industries.

Somewhat surprisingly, at least given some popular perceptions of the new economy, when we look at new economy jobs classified on the basis of employment in high-tech industries, we do not find greater use of contingent or alternative employment relationships. In fact, these types of employment relationships are somewhat less prevalent in high-tech industries with the exception of management and public relations services. However, when we classify new economy workers based on residence in hightech cities, contingent and alternative employment relationships are more common, even after accounting for the faster employment growth in these cities. These differentials are in part attributable to the overall industrial mix of employment in these cities, although this extends beyond employment in the typical "high-tech" industries. Combining all contingent and alternative categories, workers in new economy jobs classified in this way are 8 percent more likely to be in contingent or alternative employment arrangements. Defining "new economy" more literally to be those industries with the fastest growth yields the most striking differences, as workers in the 20 fastest-growing industries are more than 60 percent more likely to be in contingent or alternative employment relationships, although a large chunk of this difference is driven 
by employment in the fast-growing construction and personnel supply services industries where employment is perhaps "intrinsically" contingent or alternative.

Of course, the numbers are only suggestive, as-even under the most favorable view of our means of identifying new economy jobs-we do not have a rigid sorting of workers into new economy jobs and other jobs, but rather into groups of workers in which new economy jobs are more and less prevalent. This suggests that the "true" differential between new economy jobs and other jobs could be considerably larger. While the exact magnitudes of the differentials are therefore uncertain, the data nonetheless indicate significantly greater use of contingent and alternative employment relationships in new economy jobs when these jobs are defined by employment in high-tech cities, and what would have to be considered large differences between new economy jobs and other jobs when new economy jobs are defined by employment in fast-growing industries.

To the extent that the personnel supply services industry is a feature of the new economy, and continues its rapid growth, it will contribute an increasing share of contingent employment. Furthermore, it has clearly grown into a non-trivial industry, exceeding 2 percent of total employment in the late 1990s (Houseman and Polivka, 2000), and although the industry cannot indefinitely continue its past growth rate of 11 percent per year from 1972 to 1995 (Segal and Sullivan, 1997), it clearly has the potential to partially drive aggregate trends in contingent and alternative employment relationships. ${ }^{48}$ Nonetheless, based on the evidence we present, there appears to be a general link between the new economy and greater reliance on contingent or alternative employment relationships, and not solely growing contingent and alternative employment stemming from the emergence and rapid growth of the personnel supply services industry.

Our findings, of course, do not speak to the general notion of the relationship between the new economy and contingent or alternative employment. Rather, they speak only to the relationship based on

\footnotetext{
${ }^{48}$ For example, if the rate of contingent employment is 45 percent in this industry (as reported earlier) vs. 3 percent in all other industries, and employment in this industry grows from 2 to 4 percent of total employment, then the prevalence of contingent employment in the economy would rise from 3.8 percent to 4.7 percent. However, note that despite the relatively rapid growth of employment in the personnel supply services industry in the latter part of the 1990's (although still relative to a small base), Table 5 showed no growth over this period in the share of the workforce working for temporary help agencies or in the share of the workforce classified as contingent.
} 
our classifications of new economy jobs. As such, what do the findings imply? Does the development of the new economy presage the erosion of the traditional employment relationship? Employment in hightechnology industries, per se, is not associated with less reliance on the traditional employment relationship. However, one of the motivations for looking at high-tech cities was to capture employment in the jobs that more typically grow up and develop around these high-tech industries, and the greater use of contingent and alternative employment in high-tech cities indicates that such employment is less likely to use the traditional relationship. To the extent that the high-tech city classification of new economy jobs focuses on jobs that do not rely on high-tech employment per se, but rather jobs that are intertwined with high-tech industries, the experiences of workers in high-tech cities may provide us with some basis for predicting what will happen as the economy as a whole moves in the directions experienced first in these cities (assuming this occurs). Looking at the data this way provides a basis for expecting some erosion of traditional employment relationships, although not dramatic changes.

But in terms of predicting future changes in the employment relationship, there is some intuitive appeal to getting away from a priori classifications of industries or cities, and simply looking at the fastestgrowing industries, as these industries are most likely to represent a growing share of employment and hence, in the most literal sense, to develop into the new economy. The analysis of new economy jobs based on industry employment growth does point more strongly to erosion of traditional employment relationships. Of course to some extent growth, per se, may be the prime determinant of reliance on contingent or alternative employment, rather than something intrinsic about the growing industries. Thus, as these industries mature and presumably experience slowing growth, reliance on contingent and alternative employment may fall. In addition, it is conceivable that at the end of a very long expansion in the late 1990s, perhaps due to an expectation that growth must eventually slow, relatively more new hiring may have been done on a contingent basis. These are questions that cannot be answered from the available data. In this regard, though, the important contribution played by the personnel supply services industry is informative, as this industry is intrinsically based on contingent and alternative work. It is only a matter of conjecture, of course, as to how large this industry can grow, but its apparently inevitable larger share in the 
U.S. economy does presage a possibly significant and long-lasting increase in contingent and alternative employment relationships.

It is important to emphasize the provisional nature of these conclusions, however. The plethora of meanings of the phrase "new economy," as well as the difficulty of operationalizing particular meanings of the phrase, imply that researchers are likely to come up with a multitude of different ways of measuring the new economy, and any of these are likely to have some subjective component. We have tried to focus on objective criteria for classifying new economy jobs, when possible based on studies done prior to this one. But we strongly suspect that a few years down the road numerous other studies will propose and consider different ways of classifying new economy jobs, and the answers one gets to questions about employment relationships in the new economy may depend on how these jobs are classified. Thus, this paper may ultimately serve more to raise these questions and stimulate research on this topic than to provide definitive answers. 


\section{$\underline{\text { References }}$}

Albrecht, Karl, and Ron Zemke. 1985. Service America! Doing Business in the New Economy (Homewood, Illinois: Dow Jones-Erwin).

Autor, David H., Lawrence F. Katz, and Alan B. Krueger. 1998. "Computing Inequality: Have Computers Changed the Labor Market?" Quarterly Journal of Economics, Vol. 113, No. 4, November, pp. 1169-213.

Bahr, Morton. 2000. Remarks to the Communications Workers of America $62^{\text {nd }}$ Convention.

Barley, Stephen R. 1996. "Technicians in the Workplace: Ethnographic Evidence for Bringing Work into Organization Studies.” Administrative Sciences Quarterly, Vol. 41, pp. 404-41.

Bartel, Ann P., and Frank R. Lichtenberg. 1987. "The Comparative Advantage of Educated Workers in Implementing New Technology." Review of Economics and Statistics, Vol. 69, No. 1, February, pp. 1-11.

Batt, Rosemary. 1999. "Work Organization, Technology, and Performance in Customer Service and Sales." Industrial and Labor Relations Review, Vol. 52, No. 4, July, pp. 539-61.

Black, Sandra E., and Lisa M. Lynch. 2000. "What's Driving the New Economy: The Benefits of Workplace Innovation.” NBER Working Paper No. 7479, January.

Bond, Stephen R., and Jason G. Cummins. 2000. "The Stock Market and Investment in the New Economy: Some Tangible Facts and Intangible Fictions.” Brookings Papers on Economic Activity, No. 1, pp. 61-108.

Boslett, Mark. 2000. "Showdown at Verizon.” The Standard, August 4.

Bresnahan, Timothy F., Erik Brynjolfsson, and Lorin M. Hitt. 1999. "Information Technology, Workplace Organization and the Demand for Skilled Labor: Firm-level Evidence.” NBER Working Paper No. 7136, May.

Business and Industry Advisory Committee to the OECD. 2001. "Firms, Workers and the Changing Workplace': Considerations for the Old and the New Economy.” BIAC Discussion Paper, February 23.

Cohany, Sharon R. 1998. "Workers in Alternative Employment Arrangements: A Second Look." Monthly Labor Review, November, pp. 3-21.

Cortright, Joseph, and Heike Mayer. 2001. High-tech Specialization: A Comparison of High-technology Centers, The Brookings Institution, Washington, DC, Survey Series.

D’Andrea Tyson, Laura. 2001. "Why the New Economy is Here to Stay.” BusinessWeek Online, April 30.

DeLong, J. Bradford, and Lawrence H. Summers. 2001. "The "New Economy": Background, Historical Perspective, Questions, and Speculations." In Economic Policy for the Information Economy (Kansas City: Federal Reserve Bank of Kansas City), pp. 11-46.

DeVol, Ross. 1999. America's High-Tech Economy, Milken Institute, Santa Monica, CA.

Giarini, Orio, ed. 1987. The Emerging Service Economy (Oxford: Pergamon Press).

Ginzberg, Eli. 1984. "The Service Economy and the Changing Job Structures.” In Robert A. Ullrich, ed. The American Work Force: Labor and Employment in the 1980s (Dover, MA: Auburn House), pp. 81-94. 
Gordon, Robert J. 2000. "Does the "New Economy” Measure up to the Great Inventions of the Past?" NBER Working Paper No. 7833, August.

Hecker, Daniel. 1999. "High-Technology Employment: A Broader View.” Monthly Labor Review, June, pp. 1828.

Hipple, Steven. 1998. "Contingent Work: Results from the Second Survey.” Monthly Labor Review, November, pp. 22-35.

Houseman, Susan N., and Anne E. Polivka. 2000. "The Implications of Flexible Staffing Arrangements for Job Stability." In David Neumark, ed. On the Job: Is Long-Term Employment a Thing of the Past? (NY: Russell Sage Foundation), pp. 427-62.

Inman, Robert P., ed. 1985. Managing the Service Economy: Prospects and Problems (Cambridge: Cambridge University Press).

Mandel, Michael J. 1999. “The Prosperity Gap.” BusinessWeek Online, September 27.

Miller, Rich. 2001. “The New Economy Lives On.” BusinessWeek Online, May 10.

Neumark, David, ed. 2000. On the Job: Is Long-Term Employment a Thing of the Past? (NY: Russell Sage Foundation).

Neumark, David, Daniel Polsky, and Daniel Hansen. 1999. "Has Job Stability Declined Yet? New Evidence for the 1990s." Journal of Labor Economics, Vol. 17, No. 4, Pt. 2, October, pp. S29-64.

Paton, Dean. 1999. "Seattle's Rise as the Capital of the New Economy." Christian Science Monitor, November 30.

Polivka, Anne E. 1996. "Contingent and Alternative Work Arrangements, Defined." Monthly Labor Review, October, pp. 3-9.

Progressive Policy Institute. 2001. The Metropolitan New Economy Index, Washington, DC.

Reich, Robert. 2001. The Future of Success (New York: Alfred A. Knopf).

Schiffrin, Anya. 2000. "What's So New About the New Economy?” The Standard, November 6.

Segal, Lewis M., and Daniel G. Sullivan. 1997. “The Growth of Temporary Services Work.” Journal of Economic Perspectives, Vol. 11, No. 2, Spring, pp. 117-36.

Shepard, Stephen B. 1997. "The New Economy: What It Really Means.” BusinessWeek Online, November 17.

Sunnucks, Mike. 2001. “As Pittsburgh Builds its High-Tech Sector, Past Plays a Role in its Future.” Pittsburgh Business Times, January 5.

Triplett, Michael. 2000. "Protecting Yourself in The Dot-Com Job Market." Gfn.com, The Gay Financial Network, July 31.

U.S. Department of Commerce. 1999. “The Emerging Digital Economy II.” June. 
U.S. Department of Commerce. 2000. "Service Industries-New Economy's Biggest Generator of Jobs; Mississippi Leads States, Census Bureau Reports.” June 29.

U.S. Department of Labor. 1999. "Contingent and Alternative Employment Arrangements, February 1999." December 21.

Valletta, Robert G. 1999. "Declining Job Security.” Journal of Labor Economics, Vol. 17, No. 4, Pt. 2, October, pp. S170-97.

Varian, Hal J. 2001. "High-Technology Industries and Market Structure." In Economic Policy for the Information Economy (Kansas City: Federal Reserve Bank of Kansas City), pp. 65-102. 
Table 1: New Economy Industries Based on Technological and Scientific Employment

\begin{tabular}{|l|c|}
\hline Industries & $\begin{array}{c}\text { Information } \\
\text { technology }\end{array}$ \\
\hline Agricultural chemicals & \\
\hline Aircraft and parts & Yes \\
\hline Computer and data processing services & Yes \\
\hline Computers and related equipment & \\
\hline Construction and material handling machines & \\
\hline Drugs & \\
\hline $\begin{array}{l}\text { Electrical machinery, equipment, and supplies, } \\
\text { n.e.c. }\end{array}$ & \\
\hline $\begin{array}{l}\text { Engineering, architectural, and surveying } \\
\text { services }\end{array}$ & \\
\hline Engines and turbines & \\
\hline Guided missiles, space vehicles, and parts & \\
\hline Industrial and miscellaneous chemicals & \\
\hline Machinery, except electrical, n.e.c. & \\
\hline Management and public relations services & \\
\hline $\begin{array}{l}\text { Medical, dental, \& optical instruments and } \\
\text { supplies }\end{array}$ & Yes \\
\hline Motor vehicles and motor vehicle equipment & \\
\hline Office and accounting machines & Yes \\
\hline Ordnance & \\
\hline Paints, varnishes, and related products & Yes \\
\hline Petroleum refining & \\
\hline Photographic equipment and supplies & Yes \\
\hline Plastics, synthetics, and resins & \\
\hline Radio, T.V., and communication equipment & \\
\hline Research, development, and testing services & \\
\hline Scientific and controlling instruments & \\
\hline Soaps and cosmetics & \\
Source:Hecker (1999) The Heckes sty lists & industies \\
\hline
\end{tabular}

Source: Hecker (1999). The Hecker study lists 29 industries based on SIC codes. As the CPS data we analyze use Census industry codes, we used a cross-walk between SIC and Census industry codes, resulting in the 25 Census industries shown here. The information-technology industries are based on U.S. Department of Commerce (1999). 
Table 2: Top 10 New Economy Cities Based on High-Technology Employment

\begin{tabular}{|l|c|}
\hline City & $\begin{array}{l}\text { Share of employment (\%) in } \\
\text { high-technology industry }\end{array}$ \\
\hline San Jose, CA PMSA & 36.42 \\
\hline Austin-San Marcos, TX MSA & 21.49 \\
\hline Raleigh-Durham-Chapel Hill, NC MSA & 16.53 \\
\hline Washington, DC-MD-VA-WV PMSA & 13.45 \\
\hline Boston, MA-NH PMSA & 14.81 \\
\hline Portland-Vancouver, OR-WA PMSA & 13.98 \\
\hline Seattle-Bellevue-Everett, WA PMSA & 16.22 \\
\hline Minneapolis-St. Paul, MN-WI MSA & 14.17 \\
\hline Phoenix-Mesa, AZ MSA & 11.00 \\
\hline San Diego, CA MSA & 14.64 \\
\hline Other large cities & 10.21 \\
\hline Source: The ist of cities & $12001,126)$. \\
\hline
\end{tabular}

Source: The list of cities comes from Cortright and Mayer (2001, Table 3). The cities are ranked from top to bottom based on the study's total high-tech employment "location quotient." The shares in the second column are for employment in the 25 industries listed in Table 1. They are computed (using sample weights) from the CWS 1997, 1999, and 2001 files; the 1995 supplement is not used because it does not have city codes. The last row includes the 51 additional cities with more than 500,000 workers on average over the 1996-2000 period. 
Table 3: Top 20 New Economy Industries Based on Growth, Ranked

\begin{tabular}{|l|c|}
\hline Industry & $\begin{array}{c}\text { Growth in employment } \\
\text { share, } 1996 \text { to 2000 }\end{array}$ \\
\hline $\begin{array}{l}\text { Computer and data processing } \\
\text { services }\end{array}$ & .806 \\
\hline Construction & .659 \\
\hline Elementary and secondary schools & .277 \\
\hline Telephone communications & .186 \\
\hline $\begin{array}{l}\text { Security, commodity brokerage, and } \\
\text { investment companies }\end{array}$ & .170 \\
\hline Personnel supply services & .151 \\
\hline $\begin{array}{l}\text { Management and public relations } \\
\text { services }\end{array}$ & .146 \\
\hline Child day care services & .130 \\
\hline Credit agencies, n.e.c. & .129 \\
\hline Trucking Services & .124 \\
\hline $\begin{array}{l}\text { Engineering, architectural, and } \\
\text { surveying services }\end{array}$ & .112 \\
\hline Business services, n.e.c. & .088 \\
\hline $\begin{array}{l}\text { Professional and commercial equipment } \\
\text { and supplies }\end{array}$ & .085 \\
\hline Lumber and building material retailing & .078 \\
\hline Drug stores & .069 \\
\hline Offices and clinics of physicians & .065 \\
\hline Health services, n.e.c. & .061 \\
\hline $\begin{array}{l}\text { Miscellaneous entertainment and } \\
\text { recreation services }\end{array}$ & .058 \\
\hline Miscellaneous retail stores & .056 \\
\hline Air transportation & .049 \\
\hline Source: Authors calculions based & \\
\hline
\end{tabular}

Source: Authors' calculations based on CPS ORG files, weighted estimates. Calculation described in text. Industries that also appear in Table 1 are highlighted in boldface. The second column shows the growth in the employment shares between the 1996 and 2000 ORG files (annual averages). 
Table 4: Breakdowns of Employment in New Economy Cities

\begin{tabular}{|l|c|c|}
\hline City & $\begin{array}{l}\text { Share of employment (\%) in } \\
\text { high-tech and high-growth } \\
\text { industries }\end{array}$ & $\begin{array}{l}\text { Share of employment (\%) in } \\
\text { high-growth industries, but not } \\
\text { high-tech industries }\end{array}$ \\
\hline San Jose, CA PMSA & 9.65 & 19.29 \\
\hline Austin-San Marcos, TX MSA & 6.86 & 22.56 \\
\hline Raleigh-Durham-Chapel Hill, NC MSA & 4.42 & 25.56 \\
\hline Washington, DC-MD-VA-WV PMSA & 9.29 & 23.98 \\
\hline Boston, MA-NH PMSA & 6.86 & 24.91 \\
\hline Portland-Vancouver, OR-WA PMSA & 4.58 & 26.95 \\
\hline Seattle-Bellevue-Everett, WA PMSA & 5.64 & 21.75 \\
\hline Minneapolis-St. Paul, MN-WI MSA & 5.24 & 25.78 \\
\hline Phoenix-Mesa, AZ MSA & 3.84 & 29.71 \\
\hline San Diego, CA MSA & 5.11 & 26.62 \\
\hline Other large cities & 3.56 & 27.55 \\
\hline
\end{tabular}

Source: Authors' calculations, weighted estimates. See notes to Tables 1-3. The second column refers to the boldfaced industries in Table 3 (those which also appear in Table 1), while the third column refers to the remaining industries in Table 3. The shares are computed from the CWS 1997, 1999, and 2001 files. 
Table 5: Descriptive Statistics on Contingent and Alternative Employment

\begin{tabular}{|c|c|c|c|c|c|c|c|}
\hline \multirow[t]{3}{*}{ thes } & \multirow[b]{2}{*}{1995} & \multirow[b]{2}{*}{1997} & \multirow[b]{2}{*}{1999} & \multirow[b]{2}{*}{2001} & \multicolumn{3}{|c|}{ All years } \\
\hline & & & & & All & $\begin{array}{l}\text { Not in } \\
\text { school }\end{array}$ & $\begin{array}{l}\text { Not in school, } \\
\text { age } 18-65\end{array}$ \\
\hline & (1) & (2) & (3) & (4) & (5) & (6) & (7) \\
\hline \multicolumn{8}{|l|}{ Contingent work } \\
\hline Contingent-most restrictive & $\begin{array}{l}2.21 \\
(.06)\end{array}$ & $\begin{array}{l}1.88 \\
(.06)\end{array}$ & $\begin{array}{l}1.84 \\
(.06)\end{array}$ & $\begin{array}{l}1.70 \\
(.07)\end{array}$ & $\begin{array}{l}1.90 \\
(.03)\end{array}$ & $\begin{array}{l}1.50 \\
(.03)\end{array}$ & $\begin{array}{l}1.49 \\
(.03)\end{array}$ \\
\hline Contingent-less restrictive & $\begin{array}{l}2.79 \\
(.07)\end{array}$ & $\begin{array}{l}2.46 \\
(.07)\end{array}$ & $\begin{array}{l}2.30 \\
(.07)\end{array}$ & $\begin{array}{l}2.22 \\
(.08)\end{array}$ & $\begin{array}{l}2.44 \\
(.03)\end{array}$ & $\begin{array}{l}2.03 \\
(.03)\end{array}$ & $\begin{array}{l}2.03 \\
(.03)\end{array}$ \\
\hline Contingent-most broad & $\begin{array}{l}4.85 \\
(.09)\end{array}$ & $\begin{array}{l}4.38 \\
(.09)\end{array}$ & $\begin{array}{l}4.24 \\
(.09)\end{array}$ & $\begin{array}{l}3.98 \\
(.10)\end{array}$ & $\begin{array}{l}4.35 \\
(.05)\end{array}$ & $\begin{array}{l}3.74 \\
(.04)\end{array}$ & $\begin{array}{l}3.67 \\
(.04)\end{array}$ \\
\hline \multicolumn{8}{|l|}{ Alternative work } \\
\hline Independent contractor & $\begin{array}{l}6.80 \\
(.11)\end{array}$ & $\begin{array}{l}6.74 \\
(.11)\end{array}$ & $\begin{array}{l}6.35 \\
(.11)\end{array}$ & $\begin{array}{l}6.48 \\
(.13)\end{array}$ & $\begin{array}{l}6.59 \\
(.06)\end{array}$ & $\begin{array}{l}6.93 \\
(.06)\end{array}$ & $\begin{array}{l}6.68 \\
(.06)\end{array}$ \\
\hline On-call & $\begin{array}{l}1.59 \\
(.05)\end{array}$ & $\begin{array}{l}1.57 \\
(.06)\end{array}$ & $\begin{array}{l}1.54 \\
(.05)\end{array}$ & $\begin{array}{l}1.56 \\
(.06)\end{array}$ & $\begin{array}{l}1.57 \\
(.03)\end{array}$ & $\begin{array}{l}1.49 \\
(.03)\end{array}$ & $\begin{array}{l}1.42 \\
(.03)\end{array}$ \\
\hline Temporary help agency & $\begin{array}{c}.96 \\
(.04) \\
\end{array}$ & $\begin{array}{l}1.03 \\
(.04)\end{array}$ & $\begin{array}{r}.89 \\
(.04) \\
\end{array}$ & $\begin{array}{l}.88 \\
(.05) \\
\end{array}$ & $\begin{array}{c}.94 \\
(.02)\end{array}$ & $\begin{array}{c}.95 \\
(.02)\end{array}$ & $\begin{array}{c}.95 \\
(.02)\end{array}$ \\
\hline Contract firm & $\begin{array}{l}.48 \\
(.03)\end{array}$ & $\begin{array}{l}.61 \\
(.03)\end{array}$ & $\begin{array}{l}.53 \\
(.03)\end{array}$ & $\begin{array}{c}.44 \\
(.03)\end{array}$ & $\begin{array}{l}.51 \\
(.02)\end{array}$ & $\begin{array}{l}.53 \\
(.02)\end{array}$ & $\begin{array}{l}.53 \\
(.02)\end{array}$ \\
\hline Any alternative arrangement & $\begin{array}{l}9.84 \\
(.12) \\
\end{array}$ & $\begin{array}{l}9.96 \\
(.13)\end{array}$ & $\begin{array}{l}9.31 \\
(.13)\end{array}$ & $\begin{array}{l}9.35 \\
(.15)\end{array}$ & $\begin{array}{l}9.61 \\
(.07)\end{array}$ & $\begin{array}{l}9.89 \\
(.07)\end{array}$ & $\begin{array}{l}9.58 \\
(.07)\end{array}$ \\
\hline \multicolumn{8}{|l|}{ Contingent or alternative } \\
\hline Full sample & $\begin{array}{l}13.16 \\
(.14)\end{array}$ & $\begin{array}{l}12.99 \\
(.15)\end{array}$ & $\begin{array}{l}12.34 \\
(.14)\end{array}$ & $\begin{array}{l}12.11 \\
(.17)\end{array}$ & $\begin{array}{l}12.64 \\
(.07)\end{array}$ & $\begin{array}{l}12.36 \\
(.08)\end{array}$ & $\begin{array}{l}12.00 \\
(.08)\end{array}$ \\
\hline \multicolumn{8}{|l|}{ Byeducation } \\
\hline H.S. diploma or less & $\begin{array}{l}12.21 \\
(.14)\end{array}$ & $\begin{array}{l}11.86 \\
(.14)\end{array}$ & $\begin{array}{l}11.38 \\
(.15)\end{array}$ & $\begin{array}{l}11.75 \\
(.17)\end{array}$ & $\begin{array}{l}11.80 \\
(.07)\end{array}$ & $\begin{array}{l}11.66 \\
(.07)\end{array}$ & $\begin{array}{l}11.35 \\
(.07)\end{array}$ \\
\hline Bachelor's or more & $\begin{array}{l}14.73 \\
(.15) \\
\end{array}$ & $\begin{array}{l}14.82 \\
(.16)\end{array}$ & $\begin{array}{l}13.61 \\
(.15)\end{array}$ & $\begin{array}{l}12.45 \\
(.17)\end{array}$ & $\begin{array}{l}13.84 \\
(.08) \\
\end{array}$ & $\begin{array}{l}13.67 \\
(.08) \\
\end{array}$ & $\begin{array}{l}13.13 \\
(.08)\end{array}$ \\
\hline Sample size & 57,146 & 51,161 & 51,541 & 38,116 & 197,964 & 186,505 & 180,908 \\
\hline
\end{tabular}

Source: Authors' calculations, CWS 1995, 1997, 1999, and 2001, weighted estimates. Percentages are reported, with standard errors of means in parentheses. Work may be classified as both contingent and alternative, so the "contingent or alternative" row (for the full sample) is typically less than the sum of the two categories.

Observations are limited to employed civilians aged 18-65, excluding unpaid family members. For the H.S. diploma or less sample, the sample size in column (7) is 76,389. For the Bachelor's or more sample, the sample size in column (7) is 53,069. Non-respondents to the supplements were dropped. Individuals in school are defined as those in school either part-time or full-time. 
Table 6: Contingent and Alternative Employment: New Economy Workers Based on Employment in High-Tech Industries

\begin{tabular}{|c|c|c|c|c|c|c|}
\hline & \multicolumn{3}{|c|}{ Means } & \multicolumn{3}{|c|}{ Regression-adjusted estimates } \\
\hline & $\begin{array}{l}\text { New } \\
\text { economy } \\
\text { industries }\end{array}$ & $\begin{array}{c}\text { Other } \\
\text { industries }\end{array}$ & Difference & $\begin{array}{l}\text { Include } \\
\text { individual } \\
\text { controls }\end{array}$ & $\begin{array}{l}\text { Add controls for } \\
\text { industry size and } \\
\text { growth }\end{array}$ & $\begin{array}{c}\text { Only information } \\
\text { technology industries } \\
\text { classified as high-tech }\end{array}$ \\
\hline & $(1)$ & (2) & (3) & (4) & $(5)$ & (6) \\
\hline \multicolumn{7}{|l|}{ Contingent work } \\
\hline $\begin{array}{l}\text { Contingent-most } \\
\text { restrictive }\end{array}$ & $\begin{array}{l}.94 \\
(.07)\end{array}$ & $\begin{array}{l}1.56 \\
(.03)\end{array}$ & $\begin{array}{l}-.62 \\
(.08)\end{array}$ & $\begin{array}{l}-.56 \\
(.08)\end{array}$ & $\begin{array}{l}-.70 \\
(.08)\end{array}$ & $\begin{array}{l}-1.44 \\
(.41)\end{array}$ \\
\hline $\begin{array}{l}\text { Contingent-less } \\
\text { restrictive }\end{array}$ & $\begin{array}{l}1.48 \\
(.09)\end{array}$ & $\begin{array}{l}2.09 \\
(.04)\end{array}$ & $\begin{array}{l}-.62 \\
(.10)\end{array}$ & $\begin{array}{l}-.49 \\
(.10)\end{array}$ & $\begin{array}{l}-.89 \\
(.10)\end{array}$ & $\begin{array}{l}-1.94 \\
(.77) \\
\end{array}$ \\
\hline Contingent-most broad & $\begin{array}{l}2.84 \\
(.13) \\
\end{array}$ & $\begin{array}{l}3.77 \\
(.05) \\
\end{array}$ & $\begin{array}{c}.93 \\
(.13) \\
\end{array}$ & $\begin{array}{l}-.86 \\
(.13) \\
\end{array}$ & $\begin{array}{r}-1.17 \\
(.14) \\
\end{array}$ & $\begin{array}{r}-2.60 \\
(.78) \\
\end{array}$ \\
\hline \multicolumn{7}{|l|}{ Alternative work } \\
\hline Independent contractor & $\begin{array}{l}5.04 \\
(.17)\end{array}$ & $\begin{array}{l}6.86 \\
(.06)\end{array}$ & $\begin{array}{r}-1.82 \\
(.18)\end{array}$ & $\begin{array}{l}-2.72 \\
(.20) \\
\end{array}$ & $\begin{array}{l}-4.67 \\
(.20) \\
\end{array}$ & $\begin{array}{l}-9.35 \\
(.50) \\
\end{array}$ \\
\hline On-call & $\begin{array}{c}.34 \\
(.04) \\
\end{array}$ & $\begin{array}{l}1.54 \\
(.03)\end{array}$ & $\begin{array}{l}-1.20 \\
(.05)\end{array}$ & $\begin{array}{l}-1.08 \\
(.06)\end{array}$ & $\begin{array}{l}.72 \\
(.06) \\
\end{array}$ & $\begin{array}{l}-.87 \\
(.45)\end{array}$ \\
\hline Temporary help agency & $\begin{array}{l}1.33 \\
(.09)\end{array}$ & $\begin{array}{c}.91 \\
(.02)\end{array}$ & $\begin{array}{l}.42 \\
(.09)\end{array}$ & $\begin{array}{c}.61 \\
(.09)\end{array}$ & $\begin{array}{l}-.05 \\
(.10)\end{array}$ & $\begin{array}{l}-1.01 \\
(.20) \\
\end{array}$ \\
\hline Contract firm & $\begin{array}{l}1.57 \\
(.09)\end{array}$ & $\begin{array}{c}.41 \\
(.02) \\
\end{array}$ & $\begin{array}{l}1.15 \\
(.10)\end{array}$ & $\begin{array}{l}1.06 \\
(.09) \\
\end{array}$ & $\begin{array}{l}.76 \\
(.08)\end{array}$ & $\begin{array}{l}2.10 \\
(.20) \\
\end{array}$ \\
\hline $\begin{array}{l}\text { Any alternative } \\
\text { arrangement }\end{array}$ & $\begin{array}{l}8.28 \\
(.21)\end{array}$ & $\begin{array}{l}9.73 \\
(.07)\end{array}$ & $\begin{array}{l}-1.45 \\
(.22)\end{array}$ & $\begin{array}{l}-2.14 \\
(.25)\end{array}$ & $\begin{array}{l}-4.68 \\
(.24)\end{array}$ & $\begin{array}{l}-9.13 \\
(.11)\end{array}$ \\
\hline \multicolumn{7}{|l|}{$\begin{array}{l}\text { Contingent or } \\
\text { alternative }\end{array}$} \\
\hline Full sample & $\begin{array}{l}9.75 \\
(.23) \\
\end{array}$ & $\begin{array}{l}12.26 \\
(.08) \\
\end{array}$ & $\begin{array}{l}-2.51 \\
(.24) \\
\end{array}$ & $\begin{array}{l}-3.25 \\
(.26) \\
\end{array}$ & $\begin{array}{l}-5.66 \\
(.26) \\
\end{array}$ & $\begin{array}{c}-10 . .51 \\
(.36) \\
\end{array}$ \\
\hline \multicolumn{7}{|l|}{ By education } \\
\hline H.S. diploma or less & $\begin{array}{l}5.43 \\
(.17) \\
\end{array}$ & $\begin{array}{l}11.84 \\
(.08)\end{array}$ & $\begin{array}{l}-6.41 \\
(.19)\end{array}$ & $\begin{array}{l}-7.20 \\
(.32)\end{array}$ & $\begin{array}{l}-6.69 \\
(.32) \\
\end{array}$ & $\begin{array}{c}-10.46 \\
(.20)\end{array}$ \\
\hline Bachelor's or more & $\begin{array}{l}13.61 \\
(.26) \\
\end{array}$ & $\begin{array}{l}13.05 \\
(.08) \\
\end{array}$ & $\begin{array}{l}.56 \\
(.27)\end{array}$ & $\begin{array}{l}.76 \\
(.51)\end{array}$ & $\begin{array}{l}-3.60 \\
(.50)\end{array}$ & $\begin{array}{l}-8.83 \\
(.27) \\
\end{array}$ \\
\hline
\end{tabular}

Source: Authors' calculations, CWS 1995, 1997, 1999, and 2001, weighted estimates. Observations are limited to employed civilians aged 18-65, excluding unpaid family members. The sample size is 180,908 for the full sample, 76,389 for the H.S. diploma or less sample, and 53,069 for the Bachelor's or more sample. Columns (1)-(3) report percentages, with standard errors of means (difference in means in column (3)) in parentheses. Columns (4)-(6) report regression-adjusted estimates of the difference in column (3), based on a linear probability model for employment in the indicated category, including a dummy variable for new economy industries, and other control variables. The individual controls are described in the text. In column (5), the added controls are: the number of workers in the industry averaged over 1996-2000 ORG files; and the change in the industry employment share from 1996 to 2000 (using annual averages from the ORG files). In column (6) the controls are the same as column (5) but the list of new economy industries is restricted to information technology industries (as shown in Table 1). Boot-strapped standard errors are reported in parentheses in columns (4), (5), and (6). See notes to Tables 1 and 5 for additional details. 
Table 7: Contingent and Alternative Employment: New Economy Workers Based on Residence in High-Technology Cities

\begin{tabular}{|c|c|c|c|c|c|}
\hline & \multicolumn{3}{|c|}{ Means } & \multicolumn{2}{|c|}{ Regression-adjusted estimates } \\
\hline & $\begin{array}{c}\text { New } \\
\text { economy } \\
\text { cities }\end{array}$ & $\begin{array}{l}\text { Other } \\
\text { cities }\end{array}$ & Difference & $\begin{array}{c}\text { Include } \\
\text { individual } \\
\text { controls }\end{array}$ & $\begin{array}{l}\text { Add controls for } \\
\text { city size and } \\
\text { growth }\end{array}$ \\
\hline & (1) & (2) & (3) & (4) & (5) \\
\hline \multicolumn{6}{|l|}{ Contingent work } \\
\hline $\begin{array}{l}\text { Contingent-most } \\
\text { restrictive }\end{array}$ & $\begin{array}{l}1.46 \\
(.12)\end{array}$ & $\begin{array}{l}1.39 \\
(.03)\end{array}$ & $\begin{array}{l}.07 \\
(.12)\end{array}$ & $\begin{array}{l}.15 \\
(.08)\end{array}$ & $\begin{array}{l}.24 \\
(.08)\end{array}$ \\
\hline $\begin{array}{l}\text { Contingent-less } \\
\text { restrictive }\end{array}$ & $\begin{array}{l}2.17 \\
(.14)\end{array}$ & $\begin{array}{l}1.90 \\
(.04)\end{array}$ & $\begin{array}{l}.27 \\
(.15) \\
\end{array}$ & $\begin{array}{l}.41 \\
(.09) \\
\end{array}$ & $\begin{array}{l}.47 \\
(.10)\end{array}$ \\
\hline Contingent-most broad & $\begin{array}{l}4.16 \\
(.19) \\
\end{array}$ & $\begin{array}{l}3.45 \\
(.05) \\
\end{array}$ & $\begin{array}{c}.71 \\
(.20) \\
\end{array}$ & $\begin{array}{l}.78 \\
(.11)\end{array}$ & $\begin{array}{c}.92 \\
(.12) \\
\end{array}$ \\
\hline \multicolumn{6}{|l|}{ Alternative work } \\
\hline Independent contractor & $\begin{array}{l}6.91 \\
(.25) \\
\end{array}$ & $\begin{array}{l}6.58 \\
(.07)\end{array}$ & $\begin{array}{l}.33 \\
(.26)\end{array}$ & $\begin{array}{l}.47 \\
(.14)\end{array}$ & $\begin{array}{l}.11 \\
(.15)\end{array}$ \\
\hline On-call & $\begin{array}{l}1.18 \\
(.10)\end{array}$ & $\begin{array}{l}1.43 \\
(.03)\end{array}$ & $\begin{array}{l}-.26 \\
(.11)\end{array}$ & $\begin{array}{l}-.23 \\
(.07)\end{array}$ & $\begin{array}{l}-.15 \\
(.07)\end{array}$ \\
\hline Temporary help agency & $\begin{array}{l}1.18 \\
(.10)\end{array}$ & $\begin{array}{c}.92 \\
(.03) \\
\end{array}$ & $\begin{array}{l}.25 \\
(.11)\end{array}$ & $\begin{array}{l}.40 \\
(.07) \\
\end{array}$ & $\begin{array}{l}.27 \\
(.09)\end{array}$ \\
\hline Contract firm & $\begin{array}{l}.76 \\
(.08)\end{array}$ & $\begin{array}{l}.52 \\
(.02)\end{array}$ & $\begin{array}{l}.24 \\
(.09)\end{array}$ & $\begin{array}{l}.22 \\
(.04)\end{array}$ & $\begin{array}{l}.17 \\
(.05)\end{array}$ \\
\hline $\begin{array}{l}\text { Any alternative } \\
\text { arrangement }\end{array}$ & $\begin{array}{l}10.02 \\
(.29)\end{array}$ & $\begin{array}{l}9.45 \\
(.09) \\
\end{array}$ & $\begin{array}{c}.57 \\
(.30) \\
\end{array}$ & $\begin{array}{l}.86 \\
(.17)\end{array}$ & $\begin{array}{l}.39 \\
(.20)\end{array}$ \\
\hline \multicolumn{6}{|l|}{$\begin{array}{l}\text { Contingent or } \\
\text { alternative }\end{array}$} \\
\hline Full sample & $\begin{array}{l}12.78 \\
(.32) \\
\end{array}$ & $\begin{array}{l}11.73 \\
(.09) \\
\end{array}$ & $\begin{array}{l}1.05 \\
(.34) \\
\end{array}$ & $\begin{array}{l}1.24 \\
(.19) \\
\end{array}$ & $\begin{array}{l}1.00 \\
(.21) \\
\end{array}$ \\
\hline \multicolumn{6}{|l|}{ By education } \\
\hline H.S. diploma or less & $\begin{array}{l}11.19 \\
(.31) \\
\end{array}$ & $\begin{array}{l}11.22 \\
(.09) \\
\end{array}$ & $\begin{array}{l}-.03 \\
(.32) \\
\end{array}$ & $\begin{array}{l}.20 \\
(.57) \\
\end{array}$ & $\begin{array}{l}.01 \\
(.60)\end{array}$ \\
\hline Bachelor's or more & $\begin{array}{l}13.57 \\
(.33)\end{array}$ & $\begin{array}{l}12.74 \\
(.10)\end{array}$ & $\begin{array}{c}.84 \\
(.35) \\
\end{array}$ & $\begin{array}{l}1.61 \\
(.56)\end{array}$ & $\begin{array}{l}1.40 \\
(.60)\end{array}$ \\
\hline
\end{tabular}

Source: Authors' calculations from the CWS 1997, 1999, and 2001, weighted estimates; the 1995 supplement is not used because it does not have city codes. Observations are limited to employed civilians aged 18-65, excluding unpaid family members. The sample size is 128,556 for the full sample, 53,861 for the H.S. diploma or less sample, and 38,187 for the Bachelor's or more sample. Columns (1)-(3) report percentages, with standard errors of means (difference in means in column (3)) in parentheses. Columns (4)-(6) report regression-adjusted estimates of the difference in column (3), based on a linear probability model for employment in the indicated category, including a dummy variable for new economy industries, and other control variables. See text for individual controls. In column (5), the added controls are: the number of workers in the city averaged over 1996-2000 ORG files; the change in the city employment share from 1996 to 2000 (using annual averages from the ORG files), and an indicator for non-city (but within-MSA) residence. Boot-strapped standard errors are reported in parentheses in columns (4) and (5). See notes to Tables 2, 5, and 6 for additional details. 
Table 8: Contingent and Alternative Employment: New Economy Workers Based on Employment in High-Growth Industries

\begin{tabular}{|c|c|c|c|c|c|c|}
\hline & \multicolumn{3}{|c|}{ Means } & \multicolumn{3}{|c|}{ Regression-adjusted estimates } \\
\hline & $\begin{array}{l}\text { New } \\
\text { economy } \\
\text { industries }\end{array}$ & $\begin{array}{c}\text { Other } \\
\text { industries }\end{array}$ & Difference & $\begin{array}{c}\text { Include } \\
\text { individual } \\
\text { controls }\end{array}$ & $\begin{array}{l}\text { Add controls } \\
\text { for industry } \\
\text { size }\end{array}$ & $\begin{array}{l}\text { Add controls for } \\
\text { construction and } \\
\text { personnel supply } \\
\text { services industries }\end{array}$ \\
\hline & $(1)$ & $(2)$ & $(3)$ & (4) & $(5)$ & (6) \\
\hline \multicolumn{7}{|l|}{ Contingent work } \\
\hline $\begin{array}{l}\text { Contingent-most } \\
\text { restrictive }\end{array}$ & $\begin{array}{l}2.22 \\
(.06)\end{array}$ & $\begin{array}{l}1.19 \\
(.03)\end{array}$ & $\begin{array}{l}1.02 \\
(.07)\end{array}$ & $\begin{array}{l}1.10 \\
(.12)\end{array}$ & $\begin{array}{l}.93 \\
(.13)\end{array}$ & $\begin{array}{l}-.02 \\
(.07)\end{array}$ \\
\hline $\begin{array}{l}\text { Contingent-less } \\
\text { restrictive }\end{array}$ & $\begin{array}{l}3.03 \\
(.08)\end{array}$ & $\begin{array}{l}1.62 \\
(.04)\end{array}$ & $\begin{array}{l}1.41 \\
(.08)\end{array}$ & $\begin{array}{l}1.51 \\
(.14)\end{array}$ & $\begin{array}{l}1.60 \\
(.15)\end{array}$ & $\begin{array}{l}.19 \\
(.07) \\
\end{array}$ \\
\hline Contingent-most broad & $\begin{array}{l}5.21 \\
(.10)\end{array}$ & $\begin{array}{l}3.04 \\
(.05)\end{array}$ & $\begin{array}{l}2.17 \\
(.11)\end{array}$ & $\begin{array}{l}2.20 \\
(.19)\end{array}$ & $\begin{array}{l}1.97 \\
(.20)\end{array}$ & $\begin{array}{l}.21 \\
(.10)\end{array}$ \\
\hline \multicolumn{7}{|l|}{ Alternative work } \\
\hline Independent contractor & $\begin{array}{l}9.85 \\
(.13)\end{array}$ & $\begin{array}{l}5.37 \\
(.06)\end{array}$ & $\begin{array}{l}4.48 \\
(.15)\end{array}$ & $\begin{array}{l}4.64 \\
(.24) \\
\end{array}$ & $\begin{array}{l}4.31 \\
(.25)\end{array}$ & $\begin{array}{l}2.42 \\
(.16)\end{array}$ \\
\hline On-call & $\begin{array}{l}2.28 \\
(.07)\end{array}$ & $\begin{array}{l}1.07 \\
(.03)\end{array}$ & $\begin{array}{l}1.21 \\
(.07)\end{array}$ & $\begin{array}{l}1.27 \\
(.11)\end{array}$ & $\begin{array}{l}.57 \\
(.11)\end{array}$ & $\begin{array}{l}.69 \\
(.08)\end{array}$ \\
\hline Temporary help agency & $\begin{array}{l}2.13 \\
(.06)\end{array}$ & $\begin{array}{l}.47 \\
(.02) \\
\end{array}$ & $\begin{array}{l}1.66 \\
(.07) \\
\end{array}$ & $\begin{array}{l}1.71 \\
(.10) \\
\end{array}$ & $\begin{array}{l}2.69 \\
(.11)\end{array}$ & $\begin{array}{l}.37 \\
(.05)\end{array}$ \\
\hline Contract firm & $\begin{array}{l}1.00 \\
(.04)\end{array}$ & $\begin{array}{l}.33 \\
(.02)\end{array}$ & $\begin{array}{l}.67 \\
(.05)\end{array}$ & $\begin{array}{l}.63 \\
(.09)\end{array}$ & $\begin{array}{l}.78 \\
(.09)\end{array}$ & $\begin{array}{l}.66 \\
(.05)\end{array}$ \\
\hline $\begin{array}{l}\text { Any alternative } \\
\text { arrangement }\end{array}$ & $\begin{array}{l}15.26 \\
(.16) \\
\end{array}$ & $\begin{array}{l}7.25 \\
(.07) \\
\end{array}$ & $\begin{array}{l}8.02 \\
(.17) \\
\end{array}$ & $\begin{array}{l}8.25 \\
(.30) \\
\end{array}$ & $\begin{array}{l}8.35 \\
(.31) \\
\end{array}$ & $\begin{array}{l}4.14 \\
(.19) \\
\end{array}$ \\
\hline \multicolumn{7}{|l|}{$\begin{array}{l}\text { Contingent or } \\
\text { alternative }\end{array}$} \\
\hline Full sample & $\begin{array}{l}17.86 \\
(.17) \\
\end{array}$ & $\begin{array}{l}9.59 \\
(.08) \\
\end{array}$ & $\begin{array}{l}8.26 \\
(.19) \\
\end{array}$ & $\begin{array}{l}8.43 \\
(.32) \\
\end{array}$ & $\begin{array}{l}7.95 \\
(.35) \\
\end{array}$ & $\begin{array}{l}3.66 \\
(.20) \\
\end{array}$ \\
\hline \multicolumn{7}{|l|}{ By education } \\
\hline H.S. diploma or less & $\begin{array}{l}19.84 \\
(.17)\end{array}$ & $\begin{array}{l}8.51 \\
(.08) \\
\end{array}$ & $\begin{array}{l}11.33 \\
(.19)\end{array}$ & $\begin{array}{l}11.54 \\
(.32)\end{array}$ & $\begin{array}{l}9.99 \\
(.33)\end{array}$ & $\begin{array}{l}3.37 \\
(.31)\end{array}$ \\
\hline Bachelor's or more & $\begin{array}{l}15.21 \\
(.16)\end{array}$ & $\begin{array}{l}11.93 \\
(.09) \\
\end{array}$ & $\begin{array}{l}3.28 \\
(.18) \\
\end{array}$ & $\begin{array}{l}3.55 \\
(.30) \\
\end{array}$ & $\begin{array}{l}5.63 \\
(.37) \\
\end{array}$ & $\begin{array}{l}4.31 \\
(.37) \\
\end{array}$ \\
\hline
\end{tabular}

Source: Authors' calculations from CWS 1995, 1997, 1999, and 2001, weighted estimates. Observations are limited to employed civilians aged 18-65, excluding unpaid family members. The sample size is 180,908 for the full sample, 76,389 for the H.S. diploma or less sample, and 53,069 for the Bachelor's or more sample. Columns (1)-(3) report percentages, with standard errors of means (difference in means in column (3)) in parentheses. Columns (4)-(5) report regressionadjusted estimates of the difference in column (3), based on a linear probability model for employment in the indicated category, including a dummy variable for new economy industries, and other control variables. See text for individual controls. In column (5), the added control is the number of workers in the industry averaged over 1996-2000 ORG files. Column (6) adds a dummy variable for employment in construction and a dummy variable for employment in the temporary help services industry. Boot-strapped standard errors are reported in parentheses in columns (4)-(6). See notes to Tables 3, 5, and 6 for additional details. 
Table 9: Contingent and Alternative Employment: New Economy Workers Based on Residence in HighTechnology Cities, Additional Specifications

\begin{tabular}{|c|c|c|c|c|}
\hline & \multicolumn{4}{|c|}{ Regression-adjusted estimates } \\
\hline & $\begin{array}{l}\text { Controls for } \\
\text { city size and } \\
\text { growth }\end{array}$ & $\begin{array}{l}\text { Add controls for } \\
\text { industry size and } \\
\text { growth }\end{array}$ & $\begin{array}{l}\text { Add dummy } \\
\text { for each } \\
\text { industry }\end{array}$ & $\begin{array}{l}\text { Add dummies for three } \\
\text { high-tech, fast growth } \\
\text { industries }\end{array}$ \\
\hline & (1) & (2) & (3) & (4) \\
\hline \multicolumn{5}{|l|}{ Contingent work } \\
\hline $\begin{array}{l}\text { Contingent-most } \\
\text { restrictive }\end{array}$ & $\begin{array}{l}.24 \\
(.08)\end{array}$ & $\begin{array}{c}.22 \\
(.13)\end{array}$ & $\begin{array}{l}.21 \\
(.13)\end{array}$ & $\begin{array}{l}.25 \\
(.13)\end{array}$ \\
\hline $\begin{array}{l}\text { Contingent-less } \\
\text { restrictive }\end{array}$ & $\begin{array}{c}.47 \\
(.10) \\
\end{array}$ & $\begin{array}{l}.41 \\
(.15) \\
\end{array}$ & $\begin{array}{l}.39 \\
(.15)\end{array}$ & $\begin{array}{l}.45 \\
(.15) \\
\end{array}$ \\
\hline Contingent-most broad & $\begin{array}{c}.92 \\
(.12) \\
\end{array}$ & $\begin{array}{c}.88 \\
(.21) \\
\end{array}$ & $\begin{array}{c}.81 \\
(.20) \\
\end{array}$ & $\begin{array}{c}.92 \\
(.20)\end{array}$ \\
\hline \multicolumn{5}{|l|}{ Alternative work } \\
\hline Independent contractor & $\begin{array}{l}.11 \\
(.15)\end{array}$ & $\begin{array}{l}-.15 \\
(.25)\end{array}$ & $\begin{array}{l}-.07 \\
(.23)\end{array}$ & $\begin{array}{l}-.09 \\
(.25)\end{array}$ \\
\hline On-call & $\begin{array}{l}-.15 \\
(.07)\end{array}$ & $\begin{array}{l}-.11 \\
(.11)\end{array}$ & $\begin{array}{l}-.05 \\
(.12)\end{array}$ & $\begin{array}{l}-.13 \\
(.11)\end{array}$ \\
\hline Temporary help agency & $\begin{array}{l}.27 \\
(.09)\end{array}$ & $\begin{array}{l}.19 \\
(.11)\end{array}$ & $\begin{array}{l}.19 \\
(.09)\end{array}$ & $\begin{array}{l}.25 \\
(.11)\end{array}$ \\
\hline Contract firm & $\begin{array}{l}.17 \\
(.05)\end{array}$ & $\begin{array}{l}.11 \\
(.09)\end{array}$ & $\begin{array}{c}.02 \\
(.09)\end{array}$ & $\begin{array}{l}.06 \\
(.09)\end{array}$ \\
\hline $\begin{array}{l}\text { Any alternative } \\
\text { arrangement }\end{array}$ & $\begin{array}{l}.39 \\
(.20)\end{array}$ & $\begin{array}{c}.04 \\
(.31)\end{array}$ & $\begin{array}{l}.10 \\
(.29)\end{array}$ & $\begin{array}{c}.09 \\
(.31)\end{array}$ \\
\hline \multicolumn{5}{|l|}{$\begin{array}{l}\text { Contingent or } \\
\text { alternative }\end{array}$} \\
\hline Full sample & $\begin{array}{l}1.00 \\
(.21) \\
\end{array}$ & $\begin{array}{c}.67 \\
(.35) \\
\end{array}$ & $\begin{array}{c}.65 \\
(.33) \\
\end{array}$ & $\begin{array}{c}.73 \\
(.35) \\
\end{array}$ \\
\hline \multicolumn{5}{|l|}{ By education } \\
\hline H.S. diploma or less & $\begin{array}{c}.01 \\
(.60) \\
\end{array}$ & $\begin{array}{l}-.39 \\
(.60) \\
\end{array}$ & $\begin{array}{l}-.43 \\
(.57) \\
\end{array}$ & $\begin{array}{l}.00 \\
(.60)\end{array}$ \\
\hline Bachelor's or more & $\begin{array}{l}1.40 \\
(.60) \\
\end{array}$ & $\begin{array}{l}.93 \\
(.60)\end{array}$ & $\begin{array}{l}1.15 \\
(.58)\end{array}$ & $\begin{array}{l}.87 \\
(.60)\end{array}$ \\
\hline
\end{tabular}

Source: Authors' calculations from CWS 1997, 1999, and 2001, weighted estimates; the 1995 supplement is not used because it does not have city codes. Observations are limited to employed civilians aged 18-65, excluding unpaid family members. The sample size is 128,556 for the full sample, 53,861 for the H.S. diploma or less sample, and 38,187 for the Bachelor's or more sample. Columns (1)-(4) report regressionadjusted estimates based on a linear probability model for employment in the indicated category, including a dummy variable for high-technology cities and other control variables. See text for individual controls. Column (1) repeats column (5) from Table 7. Column (2) adds industry size and growth controls (as in Table 6). Column (3) has a dummy variable for each three-digit industry. Column (4) has a dummy variable for each high-tech, high-growth industry (shown in bold in Table 3). Boot-strapped standard errors are reported in parentheses. See notes to Tables 7 for additional details. 